"A FEA e a USP respeitam os direitos autorais deste trabalho. Nós acreditamos que a melhor proteção contra o uso ilegítimo deste texto é a publicação online. Além de preservar o conteúdo motiva-nos oferecer à sociedade o conhecimento produzido no âmbito da universidade pública e dar publicidade ao esforço do pesquisador. Entretanto, caso não seja do interesse do autor manter o documento online, pedimos compreensão em relação à iniciativa e o contato pelo e-mail bibfea@usp.br para que possamos tomar as providências cabíveis (remoção da tese ou dissertação da BDTD)." 


\section{UNIVERSIDADE DE SÃO PAULO}

FACULDADE DE ECONOMIA, ADMINISTRAÇÃO E CONTABILIDADE INSTITUTO DE MATEMÁTICA E ESTATÍSTICA

MESTRADO PROFISSIONALIZANTE "MODELAGEM MATEMÁTICA EM

FINANÇAS"

Modelagem de Risco de Pré-Pagamento para Ativos de Crédito Imobiliário Brasileiro

André Trindade Secron

Pedro Paulo Schirmer

São Paulo

2003 


\title{
Modelagem de Risco de Pré-Pagamento para Ativos de Crédito Imobiliário Brasileiro
}

André Trindade Secron

\begin{abstract}
Dissertação
apresentada à Faculdade de Economia, Administração e Contabilidade e ao Instituto de Matemática e Estatística da Universidade de São Paulo para obtenção do Título de Mestre.
\end{abstract}

Orientador Pedro Paulo Schirmer

São Paulo, 2003 


\begin{abstract}
The Brazilian market is full of imperfections, which create no room for financial incentives for borrowers to prepay. Moreover, long term loans are unavailable in the market, except for some mortgage originations. These are dealt with administered subsided rates that prove to hold down prepayment rates. However, unexpected cash flows are observed in the financial system and are driven for some reasons, other than financially optimal ones. This paper aims into studying the reasons behind early repays and to model them somehow. This will provide an unique instrument for hedging and pricing these financial instruments, and hopefully, if markets converge to reduced spreads and lower costs of transaction, this study will be a reference for future prepayment modeling.
\end{abstract}




\section{INDÍCE}

1. INTRODUÇÃO

2. A RECEITA FINANCEIRA E SEUS FATORES DE INFLUÊNCIA........7

2.1 O Fator Pré-pagamento............................................................11

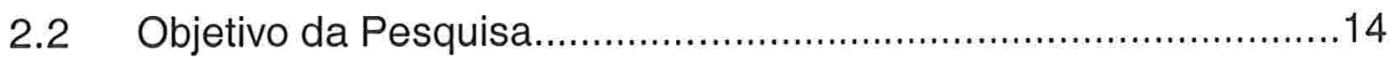

2.3 Metodologia de Pesquisa..........................................................14

3. MODELAGEM DE UM CONTRATO DE CRÉDITO IMOBILIÁRIO SEM INCERTEZA

3.1 Definição do Instrumento Financeiro...............................................16

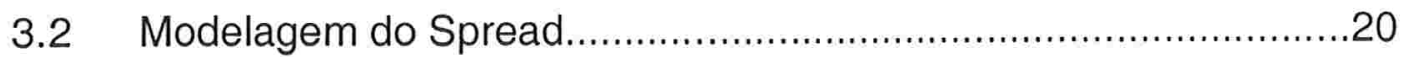

4. MODELAGEM DE UM CONTRATO DE CRÉDITO IMOBILIÁRIO COM INCERTEZA

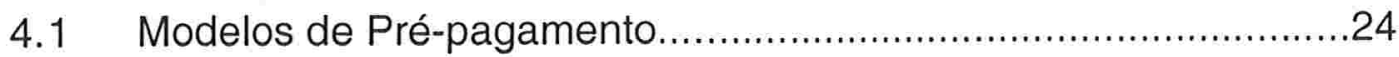

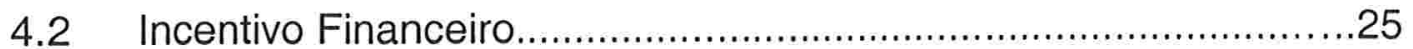

4.3 Descrição do Modelo de Pré-pagamento..........................................30

4.4 Cálculo do Fluxo de Pagamento Ajustado ao Risco........................35

4.5 Calibração do Modelo....................................................................45

5. RESULTADOS

5.1 Descrição dos Dados Utilizados....................................................49

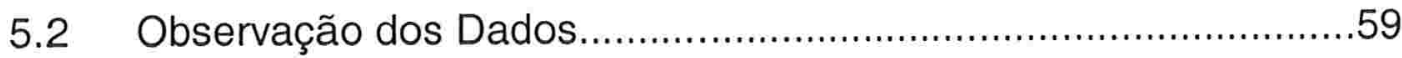

5.3 Resultados Calculados.............................................. 72

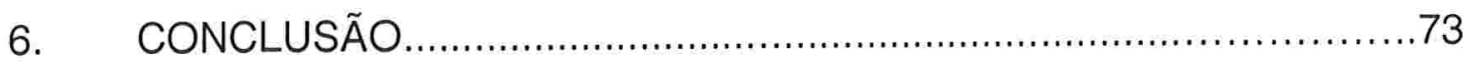

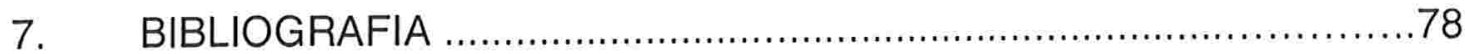

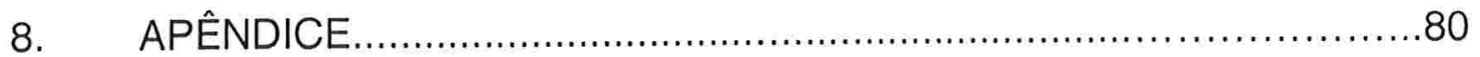




\section{INTRODUÇÃO}

Riscos podem ser denominados como fatores que influenciam o resultado de uma instituição, financeira ou não financeira. Alguns tipos de risco, que atualmente já são mensurados de maneira satisfatória, possuem ampla bibliografia disponível e métodos quantitativos de avaliação suficientemente testados ao longo das crises econômicas vivenciadas no passado.

É de se esperar que os riscos causadores de perdas financeiras de maior magnitude foram os objetos pioneiros de elaboração de estudos e métodos de controle e mensuração. São esses os riscos de crédito, riscos a variações de preços de mercado e os riscos operacionais.

Contudo, há um risco pouco discutido no mercado brasileiro que pode proporcionar resultados inesperados ao balanço de uma instituição e que requer uma análise menos intuitiva que os riscos relacionados anteriormente - é o risco de pré-pagamento.

O risco de pré-pagamento existe sempre que há a opção de antecipar pagamentos de contratos financeiros, com base em seu saldo calculado pela taxa de juro original do contrato, independente do nível corrente das taxas de juros praticadas pelo mercado no instante da antecipação.

O objetivo deste estudo é analisar os impactos no valor esperado dos fluxos de pagamento de um contrato financeiro na presença de prépagamentos. A ocorrência do evento de pré-pagamento é função de características culturais de diversos mercados, incentivos financeiros, quando existentes, e imperfeições do mercado. 
Para o propósito desta pesquisa, o instrumento financeiro selecionado foi o contrato de crédito imobiliário. Os motivos são facilmente justificáveis, já que são os empréstimos financeiros com prazos mais longos direcionados ao segmento de pessoas físicas. Este segmento forma o grupo de agentes econômicos que demonstram as características comportamentais objeto deste trabalho. O estudo espera conseguir observar um comportamento social padrão que determine a taxa de pré-pagamento.

Já é de se esperar que o incentivo financeiro não esteja presente no resultado final, por motivos que serão futuramente explorados. Por esta razão, o modelo de pré-pagamento implementado nesta pesquisa, que sugere melhor aderência ao comportamento dos agentes econômicos brasileiros considera apenas os fatores de ordem não financeiros, denominados fatores exógenos. 


\section{A RECEITA FINANCEIRA E SEUS FATORES DE INFLUÊNCIA}

Instituições financeiras têm como núcleo de atividade a intermediação financeira entre agentes econômicos, divididos entre os detentores de recursos excedentes e os que não detém recursos suficientes para saciar seu desejo de consumo. Estes, por sua vez, recorrem aos recursos excedentes na forma de financiamento ao consumo, a serem pagos acrescidos de juros, com suas rendas futuras aguardadas. De forma simplificada, é um mecanismo de antecipação da renda futura para consumo imediato. O papel da instituição financeira é colocar-se entre esses agentes, os superavitários e os deficitários, facilitando a troca de recursos financeiros e contribuindo para o bem estar das partes.

O mecanismo acima descrito permite a obtenção de receita às instituições financeiras. A diferença entre a taxa de captação e a taxa de empréstimo dos recursos, denominada taxa de spread ${ }^{1}$, configura a receita de intermediação financeira.

Nos casos mais simples, o spread pode ser apurado de modo direto, quando a instituição financeira capta recursos a juros e prazos fixos e os empresta pelo mesmo prazo, a uma taxa de juros fixa superior. Assim, o resultado financeiro em unidades monetárias será determinado pela relação entre o diferencial de taxas, prazo e volume. Cabe ressaltar que, o resultado calculado, neste exemplo, é líquido e certo, exceto em caso de inadimplência ${ }^{2}$ do financiado. Demais fatores externos relacionados às flutuações de preços de mercado, liquidez, etc., não têm influência na apuração do resultado da intermediação. No decurso do prazo do empréstimo, os recursos emprestados serão pagos acrescidos de juros, bem como ocorrerá o pagamento da captação, também acrescida de juros. A diferença entre o volume das transações cria déficit ou superávit de recursos e lucro ou prejuízo será auferido no período.

\footnotetext{
${ }^{1}$ taxa de spread: taxa adicional de risco cobrado no mercado financeiro, sobretudo internacional. É variável conforme a liquidez e as garantias do tomador, o volume do empréstimo e o prazo do resgate.
} 
Os agentes econômicos dispõem de inúmeras formas de aplicar seus recursos excedentes bem como financiar seu consumo, proporcionadas pela evolução dos mercados financeiros. Diversos índices, prazos, cláusulas de repactuações ${ }^{3}$ periódicas, instrumentos de garantias, moedas, derivativos ${ }^{4} \mathrm{e}$ inúmeras outras particularidades são atualmente oferecidos aos agentes. Essa evolução dos mercados trouxe uma profunda complexidade à apuração de resultados de intermediação financeira.

Recursos captados remunerados a um determinado índice e direcionados a empréstimos remunerados a outros índices, prazos de captações e empréstimos diferentes, atribuições específicas dos empréstimos e das captações, descasam as datas e os volumes dos fluxos de caixa futuros, de uma instituição financeira, especialmente, considerando-se que muitos índices que remuneram essas operações serão conhecidos no futuro, quando do pagamento ou recebimento dos recursos. Mais ainda, o descasamento entre $\circ$ volume de recursos captados e emprestados de diferentes características depende exclusivamente da demanda e oferta dos agentes econômicos, que varia com a conjuntura econômica, aspectos culturais, etc.

Como forma de ilustrar a complexidade em determinar o resultado da intermediação, considere um exemplo no qual a captação do recurso é remunerada à variação de inflação, expressa pelo índice geral de preços médios (IGPM) por exemplo, e sua aplicação é um financiamento remunerado a variação do dólar norte-americano, ambos pelo prazo de um ano. Ao final do prazo estipulado, apura-se a variação do índice de inflação durante os doze meses, a variação da moeda pelo mesmo período, e o resultado é determinado pela diferença entre ambos multiplicado pelo volume das operações. Neste exemplo, assumimos que os volumes das operações são idênticos. Neste

\footnotetext{
${ }^{2}$ Avaliação de risco de crédito não está no escopo desta pesquisa.

${ }^{3}$ Certos contratos financeiros oferecem a possibilidade de renegociações periódicas de sua taxa de juros.

${ }^{4}$ Instrumentos financeiros contingentes que derivam, em sua maioria, de outros ativos negociados à vista (entretanto no mercado norte-americano já existem derivativos de clima, por exemplo, que não são derivados de um ativo negociado à vista). Estão entre os mais negociados os futuros e as opções.
} 
exemplo, diferentemente do exemplo anterior, o resultado da intermediação não pode ser determinado antecipadamente e está sujeito a flutuação dos índices econômicos específicos durante o prazo da operação. Define-se então, que estão sujeitos aos riscos de variação de preços de mercado, ou apenas ao Risco de Mercado 5 .

Intuitivamente, define-se que Risco é todo e qualquer evento que influencie no resultado financeiro de uma instituição. Instituições financeiras podem incorrer em diversos riscos diferentes inerentes à sua atividade de intermediação. Ao citar os mais comuns temos, risco de taxa de juros, risco de mercado, risco de crédito, risco operacional, risco de tecnologia e risco de insolvência ("Financial Institutions Management, A Modern Perspective", Anthony Sauders, p. 73).

A indústria de finanças concentrou-se, por muito tempo, em pesquisas voltadas a compreender e gerenciar os riscos que influenciam em maior magnitude o resultado das instituições financeiras. Grande parte das pesquisas foi movida por crises no setor. O risco de crédito, por envolver perdas de maior magnitude, vem sendo gerenciado de maneira contundente há anos, pois cada evento de inadimplência de contraparte traduz-se em perda dos juros e capital investidos. É natural que instituições financeiras mantenham, há tempos, departamentos estruturados que analisem e gerenciem o risco crédito de contraparte, a fim de minimizar a exposição de seus balanços a este evento de risco. Certas crises fomentaram estudos de outros tipos de risco, como o risco de mercado. Instituições mantinham grandes posições de ativos, amplamente negociados pelo mercado, com a finalidade de obter lucro quando da venda destes ativos por preços acima dos de compra. Crises que promoveram queda generalizada dos preços dos ativos negociados no mercado foram responsáveis por prejuízos marcantes nos balanços das Instituições. A indústria passou, a partir de então, a direcionar suas pesquisas às

\footnotetext{
${ }^{5}$ Para leitura aprofundada a respeito do assunto, ver "Value at Risk - The New Benchmark for Managing Financial Risk", Jorion, Philippe (2000).
} 
movimentações em preços de ativos e criar modelos de gestão de risco de mercado de ativos financeiros.

Como resultado, atualmente existe ampla bibliografia que cobre eficientemente a gestão de certos riscos intrínsecos à atividade financeira, das quais em sua maioria são reagentes de perdas efetivamente observadas, causadas por crises setoriais e conjunturais, que, por conseqüência, seguiram a cronologia histórica destas crises.

Especificamente no mercado financeiro brasileiro, o desenvolvimento da indústria seguiu o mesmo padrão de reação às crises do setor. Alguns modelos de gestão de risco foram aplicados no mercado doméstico, após terem sido testados e comprovada sua funcionalidade no mercado de origem da pesquisa. Como os comportamentos dos mercados diferem entre si, adaptações foram necessárias e acabaram por tornar-se objeto de aprofundamento das pesquisas existentes. Com isso, o mercado financeiro brasileiro já dispõe de uma série de modelos de gestão de riscos eficientes e devidamente ajustados, calibrados e testados para o comportamento dos ativos domésticos. Pode-se mencionar como principais riscos pesquisados até o momento os riscos de crédito e de mercado.

Existe, porém, um risco presente na atividade de intermediação e ausente nas pesquisas brasileiras, possivelmente por não se intensificar em momentos de crise, ou por não ser facilmente identificado. Há outras razões para a indústria não ter direcionado esforços na pesquisa deste evento, que serão abordadas ao longo deste trabalho, mas estão relacionadas a comportamentos específicos do mercado local, associados a características culturais dos agentes econômicos brasileiros.É o Risco de Pré-pagamento.

Uma definição bastante intuitiva sobre risco está presente no trabalho "A Study of Mortgage Prepayment Risk" (Perry S., Robinson S., Rowland, J., 2001, p. 4), desenvolvido no mercado inglês:

"Se em algum momento no período pré-determinado, o financiado antecipar o pagamento do empréstimo, o 
financiador deverá encontrar aplicações alternativas aos recursos. Se as taxas de juros tiverem subido desde o empréstimo original, o financiador poderá reinvestir os recursos excedentes e gerar lucro. Se as taxas de juros tiverem caído, o financiador terá que re-investir os recursos excedentes e gerar prejuízo."

Estudos acerca deste objeto, no mercado europeu e principalmente no mercado americano foram motivados por características presentes nos instrumentos de crédito imobiliário. A securitização ${ }^{6}$ de contratos de crédito imobiliário tornou-se um dos principais negócios no mercado americano, movimentando bilhões de dólares. Nestes instrumentos, a presença do risco de pré-pagamento é intensa e altera de maneira contundente o resultado das operações e, por conseqüência, o preço a ser cobrado por elas. Como mencionado anteriormente, o tamanho deste negócio proporcionou o subsídio necessário para ser foco de pesquisa da indústria. Por esta razão, a bibliografia básica utilizada neste trabalho de pesquisa é direcionada aos mercados europeu e principalmente americano.

\subsection{O Fator Pré-pagamento}

Apesar da abundância de diferentes características de instrumentos financeiros de captação e empréstimos, que varia de acọrdo com o desejo dos agentes, instituições financeiras comumente emprestam recursos por períodos determinados e a taxas pré-fixadas. Como visto anteriormente, o resultado financeiro deste tipo de operação é facilmente apurado e não deveria sofrer alteração por qualquer evento de risco, exceto evento de inadimplência. $O$ aspecto que prevalece para conhecer este resultado é o momento que o evento, pagamento ou recebimento acontece. No caso mais simples se o empréstimo e 
a captação ocorrerem no mesmo instante, o resultado é caracterizado pela diferença dos montantes. Ora exposto que o prazo dos contratos é fixo, esperase que em determinada data, a liquidação dos recursos crie o resultado esperado.

Alguns contratos, por sua vez, podem ser pagos antecipadamente a data de vencimento, com seu respectivo saldo calculado pela taxa de juros contratual, em qualquer momento que o financiado deseje. Neste momento do trabalho, não se concentrará a discussão sobre quais as razões existentes para o financiado antecipar pagamentos. Apenas para contextualizar, os motivos podem ser de ordem pessoal, como troca de imóvel, financeira, como aumento de salário ou bonificação inesperada, ou cultural, como o simples desejo de liquidar dívidas o quanto antes ${ }^{7}$. Este direito é garantido por determinação de legislação vigente, como Código de Defesa do Consumidor $^{8}$, ou por características intrínsecas do próprio contrato.

Esta antecipação de recursos aguardados em uma data futura caracteriza o pré-pagamento.

$\mathrm{Na}$ ocorrência de antecipação de pagamento em algum momento do tempo, a instituição terá recursos extras, não programados em seu fluxo de caixa, que deverão ser reinvestidos até o prazo final original do empréstimo. A taxa de reinvestimento, porém, será determinada pelo mercado à vista, que pode ser acima ou abaixo da taxa original do empréstimo. Um mercado de juros em queda representa uma taxa de reinvestimento menor, o que reduz o resultado antes esperado do empréstimo.

Se um contrato imobiliário, cujo prazo contratual é denotado por $T$, prevê a amortização de um principal $P$ pelo pagamento de parcelas $C_{j}$ feitos em instantes pré-acordados $0=T_{0}<T_{1}<\ldots<T_{N}=T$, então o valor do contrato em $t=0$, igual a $P$, deve ser expresso pelas expectativas de pagamento das

\footnotetext{
${ }^{6}$ Criação de títulos lastreados a ativos financeiros, que podem ser negociados nos mercados de capitais.

${ }_{7}^{7}$ Razões para antecipação de resultados serão discutidos de forma detalhada, mais adiante no trabalho quando da descrição do problema.
} 
parcelas $C_{j}$ nas datas $T_{j}$, trazidas a valor presente pelas taxas de juros de mercado, sintetizadas aqui, por uma taxa de desconto instantânea $i_{t}$ vigente no tempo $t$. Assim:

$$
P=E\left[\sum_{j=0}^{N} C_{j} \cdot e^{-\int_{0}^{r_{j}} r_{d} d t}\right]
$$

A medida de probabilidade usada para calcular o valor esperado é uma medida ajustada apenas ao risco de mercado de juros.

Quando as condições contratuais permitem que uma antecipação de amortização de principal possa ocorrer, a equação acima não é mais verdadeira, pois algumas das parcelas $C_{j}$ serão pagas de acordo com as condições contratuais e outras estarão contingentes à condição de mercado e ou à condições exógenas que estão ligadas à psicologia dos agentes financiado. Neste caso, a estrutura de fluxo de pagamentos do contrato deve ser totalmente remodelada, de forma à ajustar o valor das parcelas ao risco de pré-pagamento. Isto requer um modelagem mais precisa, em cada instante de tempo, do saldo remanescente do contrato. É importante distinguir os instrumentos objeto desta pesquisa dos demais instrumentos disponíveis no mercado, nos quais a antecipação de pagamento é feita com base no saldo do instrumento calculado pela taxa de juros observada no mercado à vista.

Em suma, o problema acerca do risco de pré-pagamento está na modelagem das parcelas $C_{j}$ de um instrumento financeiro o qual possa ter seu saldo, calculado pela taxa de juros contratual, amortizado ou liquidado antecipadamente.

\footnotetext{
${ }^{8}$ Vigente quando da elaboração deste trabalho, 2003.
} 


\subsection{Objetivo da Pesquisa}

O objetivo desta pesquisa é encontrar um modelo que descreva 0 comportamento temporal dos fluxos de pagamentos inesperados de um instrumento financeiro. Como mencionado anteriormente, a ocorrência destes fluxos depende de uma série de fatores ligados a estados de mercado, conjunturais e culturais dos agentes econômicos. Não faz parte do objetivo desta pesquisa determinar os motivos inerentes às antecipações, apesar da discussão ser relevante ao problema, mas sim de propor uma função que descreva ao longo da vida de um contrato, como ocorrem as antecipação, definidas em percentual por tempo.

É objetivo que o modelo seja aplicável a qualquer instrumento financeiro que apresente risco de pré-pagamento implícito. Os parâmetros do modelo encontrados no resultado desta pesquisa serão provenientes de um determinado instrumento financeiro. Contudo, é apenas uma questão de encontrar os parâmetros relativos a outro instrumento qualquer e aplicá-los ao modelo aqui proposto, para obter-se os respectivos resultados procurados.

\subsection{Metodologia de Pesquisa}

Para a obtenção dos resultados da pesquisa foi escolhido um instrumento financeiro específico a ser estudado. Optou-se pelo contrato de crédito imobiliário do sistema financeiro brasileiro. A escolha baseou-se principalmente nos longos prazos contratuais. O mercado financeiro brasileiro é historicamente deficiente de instrumentos de longo prazo líquidos ${ }^{9}$. Deve-se considerar que contratos de crédito imobiliário não são líquidos e não há mercado secundário para negociação, todos os negócios estão concentrados

\footnotetext{
${ }^{9}$ Instrumentos líquidos são aqueles amplamente negociados no mercado, e que, portanto, têm preços para compra e venda a qualquer momento.
} 
em sua originaçãa ${ }^{10}$. Como o objetivo da pesquisa é obter o comportamento para os pagamentos antecipados dos contratos, a presença de mercado secundário não é relevante.

Portanto, os longos prazos dos contratos favorecem a observação de pré-pagamentos.

Para obtenção dos dados empíricos de pré-pagamento, serão simulados cem contratos de uma carteira imobiliária fictícia, originados desde 1990. A base histórica simulada apresentará os saldos dos contratos baseados no último dia útil de cada mês. A presença de fluxos de pagamentos antecipados será detectada pela comparação entre os saldos dos contratos de um determinado mês e do mês subseqüentes. Como as parcelas dos contratos são conhecidas, caso o saldo do contrato do mês subseqüente seja amortizado além da parcela esperada, terá havido antecipação de pagamento. As antecipações encontradas serão extraídas e apresentadas em períodos mensais.

Essa simulação reproduz fielmente as características de informações extraídas de qualquer base de dados real, proveniente de sistemas de qualquer instituição financeira. Deste modo é possivel, possibilita a aplicação desta pesquisa àqueles que detém informações reais.

Os resultados serão apresentados e a conclusão da pesquisa indicará seu sentido prático. A aplicação do modelo encontrado a contratos de empréstimos imobiliários possibilitará, na prática, calcular sua nova estrutura de fluxos de pagamentos, considerando a presença de eventos de pré-pagamento, e seu novo prazo médio esperado. Com isso, instituições financeiras poderão aplicar uma estrutura de proteção mais eficiente à sua carteira de empréstimos imobiliários.

\footnotetext{
${ }^{10}$ Referente ao termo inglês origination relativo ao processo de originar novos contratos de financiamento direto aos consumidores, estado primário.
} 


\section{MODELAGEM DE UM CONTRATO DE CRÉdITO IMOBILIÁRIO SEM INCERTEZA}

\subsection{Definição do Instrumento Financeiro}

Contratos de crédito imobiliário no mercado brasileiro são oferecidos por praticamente todas as instituições integrantes do sistema financeiro e de forma quase padronizada. Conforme regulamentação atualmente vigente $^{11}$, toda e qualquer instituição financeira que detenha depósitos em poupança devem ofertar compulsoriamente um percentual destes recursos, de acordo com definição corrente do Banco Central do Brasil, a contratos de empréstimos imobiliários. Esses contratos são caracterizados pelo desembolso dos recursos de uma única vez ao financiado, para fins de pagamento do imóvel objeto do financiamento, que os paga acrescido de juros em parcelas mensais. Apesar dos contratos poderem assumir um grande número de métodos de amortização $0^{12}$ diferentes, como amortização constante, crescente, decrescente, variado e outros, o estudo se concentra nos contratos pré-fixados de amortização crescente e parcelas constantes, os mais abrangentes no mercado. Em sua grande maioria, os contratos têm prazos que variam entre 7 e 15 anos. Esses prazos variam de acordo com o emissor do contrato, status econômico do financiado, a taxa de juros do contrato, etc. A opção pelos contratos de amortização crescente e pagamento em parcelas constantes é meramente casual, a aplicação do modelo desta pesquisa é extensível a quaisquer outros modelos de contratos, já que em cada um deles o fluxo de caixa pode ser calculado antecipadamente.

Se um contrato imobiliário, cujo prazo contratual é denotado por $T$, prevê a amortização de um principal $P$ pelo pagamento de parcelas $C_{j}$ feitos

\footnotetext{
${ }^{11}$ Resolução 2.968 de 30 de março de 2000, dispõe sobre o direcionamento dos recursos captados em depósitos de poupança pelas entidades do Sistema Brasileiro de Poupança e Empréstimos.

${ }^{12}$ Redução do principal da dívida por meio de um pagamento.
} 
em instantes pré-acordados $0=T_{0}<T_{1}<\ldots<T_{N}=T$, então $\circ$ valor do contrato em $t=0$, igual a $P$. Portanto, $P$ é definido como valor presente de conjunto dos fluxos de pagamentos futuros $C_{j}$, descontados pela taxa de juros do contrato, conforme a equação (2) abaixo:

$$
P=\sum_{j=0}^{N} C \cdot e^{-\int_{0}^{T_{j}}(r) d s}
$$

No instante $t=0$, o valor do contrato é o igual ao valor principal do empréstimo, pois não há efeito da passagem do tempo e, conseqüentemente, não há incidência de juros.

Definimos $r_{t}$ como a taxa instantânea de desconto contratual, vigente no tempo $t$ e $i_{t}$ a taxa de desconto determinada pelo mercado de juros, também vigente em $t$.

Tipicamente, $T_{j}$ será mensurado em meses e os valores $T_{j}$ serão inteiro portanto. Cabe observar que a modelagem matemática aplicada neste trabalho será feita em tempo contínuo para simplificar a álgebra envolvida.

A figura (1) a seguir representa a estrutura de fluxo de caixa de um contrato de empréstimo imobiliário.

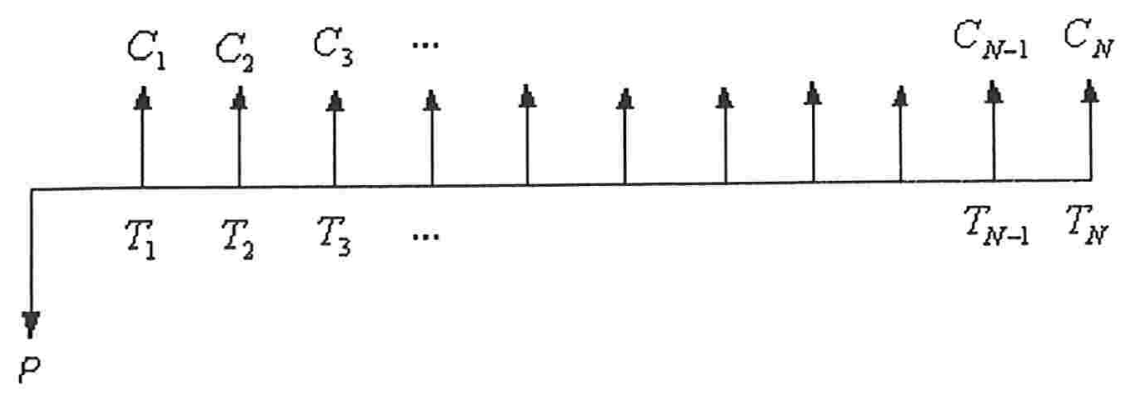

figura(1) 
Assumindo que os fluxos de pagamento $C_{j}$ sejam constantes, uma típica amortização especificada em contrato, podemos suprimir o índice de tempo $j$, e definir o valor financeiro de $C$ pela equação abaixo.

$$
C=\frac{P}{\sum_{j=0}^{N} e^{-\int_{j}^{r_{j}} r(s) d s}}
$$

A equação (3) demonstra a relação entre o valor principal do empréstimo, a taxa de juros de remuneração, o prazo e o montante das prestações periódicas, descrito por um processo contínuo.

Entretanto, a taxa de juros $r$, única para um fluxo de pagamentos constituídos por parcelas periódicas, é conhecida como taxa interna de retorno ${ }^{13}$. Esta taxa não é observada diretamente no mercado financeiro, pois o custo do dinheiro varia entre prazos diferentes.

Outra relação importante se estabelece no instante inicial do contrato. $O$ valor presente $V_{0}^{A}$ do conjunto de fluxos de pagamentos futuros descontados pelas taxas de mercado vigentes é igual ao valor do contrato, de modo que:

$$
V_{0}^{A}=\sum_{j=0}^{N} C \cdot e^{-\int_{0}^{T_{j}}(s) d s}=P=\sum_{j=0}^{N} C \cdot e^{-\int_{0}^{T_{j}}(s) d s}
$$

Postulamos que a taxa do contrato $r$ em $T_{0}$ o único valor que satisfaz a equação anterior.

\footnotetext{
${ }^{13}$ Taxa de desconto única que iguala o valor presente das parcelas futuras ao principal.
} 
Enquanto $r$ é única ao longo da vida do contrato, $i$, é dependente do tempo $t$. As taxas $i$, são determinadas pela estrutura a termo de taxa de juros (ETTJ) que usualmente é positivamente inclinada, tal que $i_{j}>i_{j-1}{ }^{14}$.

O contrato de empréstimo imobiliário tem valores intrínsecos distintos sob a diferente ótica de cada contraparte. Neste momento, é importante distinguir as contrapartes, a fim de facilitar a compreensão do problema futuramente exposto nesta pesquisa. As contrapartes são:

financiado: o detentor do passivo. Em particular, para os casos de financiamento imobiliário, é também denominado mutuário.

financiador. instituição financeira detentora do ativo.

O valor do passivo do financiado, denominado saldo da dívida, pode ser calculado em qualquer instante $t$. Sob a ótica do financiado, este montante representa o valor necessário para liquidar sua dívida em $t$.

Define-se o saldo do passivo em $t$, denotado $B_{t}^{P}$, como:

$$
B_{t}^{P}=\sum_{j=t}^{N} C \cdot e^{-\int_{j}^{T_{j}} r(s) d s}
$$

onde, $r=r(s)$ é a taxa nominal do contrato.

A contraparte financiadora do empréstimo detém um ativo a receber em parcelas conforme contrato firmado entre as partes. Sob a ótica do financiador, o valor de seu ativo é determinado pelo mercado, ou seja, valor pelo qual outra instituição adquire ${ }^{15} \circ$ direito de receber as parcelas futuras deste contrato, ou pelo custo do financiador de acessar o mercado de derivativos a fim de proteger cada parcela futura a receber individualmente. Em ambos os casos,

\footnotetext{
${ }^{14}$ Modelos que descrevem a ETTJ podem ser encontrados em "Financial Calculus, An Introduction to Derivatives Pricing", Baxter, M. e Rennie, A ., capítulo 5.

${ }^{15}$ possível na presença de mercado secundário líquido para este ativo especificamente.
} 
o valor do contrato depende das taxas de juros correntes no mercado e, como conseqüência, será referido como valor de mercado ao longo desta pesquisa.

O valor de mercado do ativo do financiador também pode ser calculado em qualquer instante $t$, ao descontar-se os fluxos de caixa vincendos pelas taxas de mercado vigentes.

Se $V_{1}^{A}$ denota o valor de mercado do título de saldo $B_{1}{ }^{P}$, com taxas de mercado iguais a $i=i(s)$, então $V_{t}^{A}$ pode ser calculado como:

$$
V_{t}^{A}=\sum_{j=t}^{N} C \cdot e^{-\int_{i}^{T_{j}} i^{(s) d s}}
$$

Quando $t=0$ este valor coincide com $V_{0}^{A}=P$.

\subsection{Modelagem do Spread}

Até o momento, o modelo de apreçamento de um contrato de empréstimo, com pagamentos periódicos e constantes, está incompleto por não apresentar a receita financeira que remunera o financiador pelos riscos corrente, pelas despesas operacionais, etc.

Seja $S$, a receita financeira, chamada também de spread, no momento $t$ :

$$
S_{t}=V_{t}^{A}-B_{t}^{P}
$$

Substituindo (4) em (7), temos:

$$
S_{t}=\sum_{j=t}^{N} C \cdot e^{-\int_{i(s) d s}^{r_{j}}}-\sum_{j=t}^{N} C \cdot e^{-\int^{T_{j}} r(s) d s}
$$


Como $C$ é constante determinado por (3),

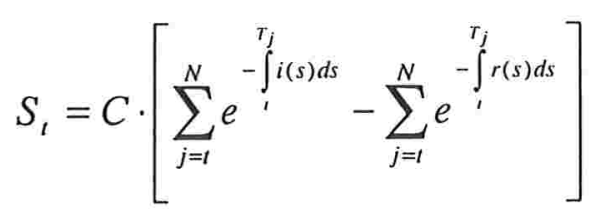

Para os fins desta pesquisa, aceitamos a hipótese de $S_{t}>0$. Esta hipótese considera que $O$ spread remunera todos os custos e inclui o componente lucro, ou seja, não é racional a existência de $S_{t} \leq 0$. A equação (9) mostra que para $S_{1}>0$, para todo $t$, é necessário que $r(s)>i(s)$, para todo $s$.

Da equação (9) pode-se deduzir o spread de duas formas distintas, que apresentam o mesmo resultado final. De acordo com a intuição individual, o spread será compreendido por qualquer um dos modelos a seguir.

Seja $x$ o spread na taxa de juros do contrato, estritamente positivo, tal que $r(s)=i(s)+x(s)$.

O conjunto de fluxos de caixa futuro passa a apresentar uma nova estrutura, já que na presença de spread $r(s)>i(s)$.

Da equação (3), que calcula o valor dos fluxos de caixa, tem-se que o valor de $C$ aumenta de acordo com o aumento do valor de $r(s)$. É direta a relação de quanto maior a taxa cobrada no contrato, maior são as parcelas de pagamento. Seja $C^{s}$ o novo fluxo de parcelas constantes calculadas a partir da taxa do contrato na presença de spread, $r(s)=i(s)+x(s)$. Se $x$ é estritamente positivo, então $C^{s}>C$, para todo $x>0$.

O spread da operação pode ser calculado, então, como: 


$$
\begin{aligned}
S_{t} & =C^{s} \cdot \sum_{j=t}^{N} e^{-\int_{j}^{r_{j}} i(s) d s}-C \cdot \sum_{j=1}^{N} e^{-\int_{j}^{r_{j} i(s) d s}} \\
& =\left(C^{s}-C\right) \cdot \sum_{j=t}^{N} e^{-\int_{j}^{\tau_{j} i(s) d s}}
\end{aligned}
$$

O spread da operação resultado de (10) é o valor presente da diferença entre as parcelas calculadas com spread $C^{s}$ e as parcelas calculadas sem spread $C$, descontada pelas taxas de mercado $i(s)$. Note que na ausência de spread, $r(s)=i(s)$.

Essa estrutura de intermediação considera que a obtenção do resultado foi garantida a partir da operação a mercado de principal idêntico ao do empréstimo, ou seja, o valor emprestado ao financiado foi obtido através de outro empréstimo do sistema financeiro, pela taxa $i(s)$ menor que $r(s)$. O spread, $x(s)$ incidente na taxa do contrato de empréstimo proporciona um fluxo de caixa de recebimentos maior que o de pagamentos. Com isso, o resultado da operação é igualmente distribuído por toda estrutura do fluxo.

Outra maneira de se obter o volume financeiro total do spread implica em estruturar as operações de modo a gerar os fluxos de pagamentos e recebimentos de mesmo valor e que o resultado provenha da diferença dos principais. A equação (9) representa este efeito:

$$
S_{t}=C \cdot\left[\sum_{j=t}^{N} e^{-\int_{i}^{r_{j} r(s) d s}}-\sum_{j=t}^{N} e^{-\int_{i}^{r_{j}}(s) d s}\right]
$$

Como na presença de $x(s), \quad r(s)>i(s), C$ multiplica um valor negativo. Apesar do valor negativo sugerir uma saída de caixa, de fato demonstra que o valor presente do passivo é maior que do ativo, que calculado 
em $T_{0}$ representa o principal de cada operação. Na prática, o recebimento do principal do passivo e o desembolso do empréstimo geram uma sobra de caixa. Como fluxos de parcelas futuras de pagamento e recebimento são equivalentes, essa sobra de caixa é o spread total da operação em $T_{0}$.

Pode-se provar que (10) e (11) são equivalentes ao se aplicar (3) em (10). O valor presente da diferença entre $C$ e $C^{s}$, existente na presença de $x(s)$ em $r(s)$, descontado por $i(s)$ em $T_{0}$ equivale a $V_{o}^{A}-B_{o}^{P}$. 


\section{MOdELAGEM DE UM CONTRATO DE CRÉdito IMOBILIÁRIO COM INCERTEZA}

\subsection{Modelos de Pré-pagamento}

Pré-pagamentos são motivados por inúmeras razões intrínsecas ao comportamento humano de cada financiado. Nas duas últimas décadas, esse comportamento tem sido um dos principais objetos de estudo da indústria de finanças, pois insere um fator contingente aos fluxos de pagamento e, conseqüentemente, ao resultado financeiro esperado. Cabe mencionar, que as pesquisas aqui referidas foram todas concentradas nos mercados americano $e$ europeu, devido a não disponibilidade de pesquisas direcionadas ao mercado brasileiro $^{16}$.

No estágio atual das pesquisas sobre pré-pagamento, o desafio tem sido modelar de maneira cada vez mais precisa e eficiente o comportamento dos detentores de financiamentos. Isto porque, obrigatoriamente, esse contrato de empréstimo é celebrado entre uma instituição financeira e um comprador de propriedade imobiliária, e as antecipações de pagamento, parciais ou totais, serão sempre uma opção do financiado. Apesar da importância em mapear o comportamento dos financiados, cabe ressaltar novamente que esse não é o objetivo desta pesquisa. Fatores de possíveis motivações para antecipações de pagamentos serão mencionados para incentivar futuras reflexões, mas a fase embrionária na qual se encontram as discussões sobre tal tema na economia brasileira requer pesquisas mais primitivas como simplesmente os impactos do pré-pagamento nos valores dos contratos e em sua estrutura de fluxos de pagamento.

Os pré-pagamentos podem ser motivados por dois grupos de fatores: endógenos e exógenos. Os fatores endógenos são caracterizados pela motivação racional, no qual existe implicitamente um benefício financeiro ao

\footnotetext{
${ }^{16}$ Não foi possível encontrar referência alguma sobre o tema direcionado ao mercado nacional, durante o prazo de pesquisa e divulgação deste trabalho.
} 
financiado em pré-pagar seu contrato. Fatores exógenos motivam de forma "irracional" o financiado a pré-pagar seu empréstimo, sem que haja o benefício direto de qualquer incentivo financeiro.

Para compreensão dos modelos racionais é preciso descrever como financiados podem adquirir benefícios financeiros com pré-pagamentos.

\subsection{Incentivo Financeiro}

Se $B_{t}^{P}$ é o valor no tempo $t$ de um empréstimo sob a ótica de um financiado e $V_{1}^{A}$ o valor de mercado do mesmo contrato de empréstimo no tempo $t$, agora sob a ótica do financiador, ocorre que em determinado cenário econômico $V_{t}^{A}>B_{t}^{P}$. Conclui-se da equação (4) que $e^{-\int_{0}^{\tau_{f}}(s) d s}>e^{-\int_{0}^{T_{f}} r(s) d s}$, obrigatoriamente.

Assumimos, também, que financiado tem livre acesso ao mercado financeiro ${ }^{17}$.

A estratégia ótima de pré-pagamento indica ao financiado que:

1. recorra ao mercado financeiro e adquira outro empréstimo de valor principal $B_{t}^{P}$.

2. pré-pague integralmente a dívida original de valor $B_{t}^{P}$.

Como resultado da estratégia, tem-se que, de acordo com (3), os valores das prestações futuras no novo contrato serão menores que as do antigo empréstimo, pois substituindo $B_{t}^{P}$ em $P$, para qualquer $i(s)<r(s), C_{n e r o r}<C_{\text {nntiso }}$. Pela equação (10), o resultado financeiro total é, em valor presente, igual a $B_{t}^{P}-V_{t}^{A}$.

\footnotetext{
${ }^{17}$ Não há imperfeições no mercado como restrição ao crédito.
} 
Esse modelo endógeno sugere que a presença de um fluxo de pagamento antecipado no tempo $t=\tau$, denominado $C_{\tau}^{P}$, está condicionada exclusivamente a taxa de juros de mercado.

As primeiras pesquisas acerca dos pré-pagamentos voltaram-se a desenvolver modelos que consideravam apenas fatores racionais. Dunn e McConnell (1981a,1981b) modelaram uma estratégia ótima de pré-pagamento que não considerava os custos de transação envolvidos. Esse modelo implicava em certas restrições de arbitragens que na prática eram usualmente violadas.

Timmis (1985), Dunn e Spatt (1986), e Johnston e Van Drunen (1988) incluíram os custos de pré-pagamento e outras friç̧ões que previnem o modelo de permitir que financiados obtenham benefícios financeiros violando restrições de arbitragem do mercado.

Seja $X_{t}$ o conjunto de todos os custos de transação definido em $t$. Como custos de transação, pode-se incluir todos os gastos extras na aquisição de um empréstimo, como por exemplo: taxa de abertura de conta, taxa contrato, impostos sobre transações financeiras e penalidades sobre antecipações de pagamento $^{18}$.

Ao incorporar-se $X_{t}$ ao modelo, a estratégia de pré-pagamento ótima apenas ocorre sob a condição

$$
B_{t}^{P}-V_{t}^{A}-X_{t}>0
$$

Essa frente de pesquisa admitia unicamente o comportamento racional dos agentes econômicos detentores de passivos imobiliários e desenvolveu modelos matemáticos que capturassem tal comportamento.

A estratégia ótima de pré-pagamento passa a ser função da taxa de juros de mercado, $i$, presente em $V_{1}^{A}$ e dos custos de transação $X_{1}$. É uma decisão unilateral que será exercida sob a condição (a). Os modelos racionais

\footnotetext{
${ }^{18}$ Presente apenas em economias nas quais pré-pagamentos são amplamente observados.
} 
aproximaram a decisão de pré-pagamento de um empréstimo ao exercício de uma opção americana ${ }^{19}$ de juros. $O$ detentor do passivo tem uma opção de compra em $V_{t}^{A}$, de preço de exercício variável no tempo igual a $B_{1}^{P} \cdot\left(1+X_{1}\right)$. O valor do passivo imobiliário sob ótica do financiado, denotado por $M_{1}^{P}$, é:

$$
M_{t}^{P}=B_{t}^{P}-V_{t}
$$

onde, $V$, é o valor da opção de pré-pagamento do financiado ${ }^{20}$.

Usando como arcabouço teórico modelos de opção de taxas de juros, ao se maximizar o valor de $V_{t}$, obtém-se os pontos no tempo de maior probabilidade de ocorrência de pré-pagamentos (Stanton, Richard., Rational Prepayment and the Valuation of Mortgage-Backed Securities, 1995, p.4), satisfeitas sempre pela condição (a). Essa classe de modelos requer um método de solução numérica, computacionalmente muito intenso. A solução envolve a calibração de uma árvore de probabilidades por onde passeia um processo estocástico de difusão de taxas de juros.

Pesquisas posteriores testaram a efetividade dos modelos endógenos de pré-pagamento, e observou-se que muitos financiados não exerciam suas opções de pré-pagamento mesmo quando ótima a condição de benefício financeiro, (a), enquanto outros agentes econômicos exerciam suas opções de pré-pagamento sob condições sub ótimas de benefícios financeiros. Era, então, evidente que os financiados, quando adquirem um financiamento imobiliário, compram opções de recompra de seus passivos, mas, raramente, as exercem sob condições ótimas. A partir desta evidência, os modelos

\footnotetext{
19 opção que pode ser exercida em qualquer momento até o vencimento do contrato. Ver Hull, John, "Options, Futures and Other Derivatives".

${ }^{20}$ esta é apenas uma referência ao modelo racional de pré-pagamento, que não é escopo desta pesquisa. Para bibliografia mais aprofundada, ver Archer, Wayne R. e Ling, David C., "Pricing Mortgage-Backed Securities: Integrating Optimal Call and Empirical Models of Prepayment', Journal of American Real State and Urban Economics Association.
} 
passaram a assumir que a condição ótima de pré-pagamento é necessária, mas não suficiente para o exercício da opção de pré-pagamento do passivo.

Essa observação empírica moveu as pesquisas subseqüentes distante dos modelos endógenos e, a partir de então, uma nova frente de pesquisas direcionou os modelos de pré-pagamento a condicionamentos por fatores exógenos. Adicionalmente, os modelos endógenos falhavam na captura de atributos usualmente observados nos pré-pagamentos imobiliários, tais como:

\section{Sazonalidade}

Foi observado que há períodos em que os financiados tendem a pré-pagar maiores volumes de seus empréstimos. Possiveis razões ligadas a este evento são períodos de reajustes salariais, bonificações e outros eventos que produzam excedente de poupança aos agentes.

\section{Prazo remanescente do contrato}

Foi contatado, que o prazo remanescente do contrato afeta diretamente a decisão de pré-pagamento do financiado. Contratos jovens são, em geral, menos suscetíveis a apresentarem pré-pagamentos. Contratos em seus meses de vida, também. Os pré-pagamentos estão concentrados em uma porção intermediária da vida dos contratos.

\section{Prazo total do contrato}

Contratos de curto prazo tendem a apresentar menor índice de pré-pagamento que contratos longos.

Por sua vez, modelos puramente exógenos (e.g., Schwartz a Torous, 1989, 1992) baseiam-se em observações empíricas do comportamento dos financiados em relação aos pré-pagamentos. Nestes modelos, prépagamentos são especificados como uma função de um conjunto de variáveis auto-explicativas. Esses modelos são bem sucedidos em capturar todas as características não racionais das decisões dos financiados. Em "Anatomy of 
Prepayments - The Salomon Smith Barney Prepayment Model' (Hayre, Lakhbir e Young, Robert, p.133), há um fator exógeno que justifica pré-pagamentos, ou seja, não relacionado a movimento na taxa de juros, conseqüentemente alheio a incentivos financeiros. Trata-se da Redução do Passivo Imobiliário. Alguns financiados têm o hábito de pagar mais que o programado no contrato, sempre que possível. Esta é uma maneira de forçar poupança, transformando sua excedente em reservas financeiras líquidas em capital imobilizado.

Este fator é particularmente interessante para o mercado brasileiro, como veremos adiante.

Essa frente de pesquisa empírica dominou, por algum tempo, entre estudiosos e negociadores do mercado imobiliário dos Estados Unidos da América. Esses modelos de apreçamento de contratos de empréstimo imobiliário utilizam um processo de Poisson $^{21}$ estimado exogenamente, para atribuir probabilidades aos eventos de pré-pagamentos. Porém, a pesada confiança em dados históricos é a maior vulnerabilidade deste modelo, que tem dificuldade em satisfazer os economistas, que não admitem passivamente que 0 comportamento do pré-pagamento seja motivado sem qualquer fundamento economicamente racional. Adicionalmente, a premissa básica de modelos econométricos é que as relações observadas no passado serão mantidas no futuro. De fato, a maior crítica ao modelo advém da sua incapacidade de capturar alterações no ambiente econômico que certamente alteram o comportamento dos mutuários.

Modelos puramente endógenos ou exógenos evoluíram aos modelos mais recentes, que combinam suas características em modelos híbridos. Modelos híbridos combinam dois processos de Poisson, um que descreve a probabilidade estimada por fatores exógenos e outro estimado por fatores endógenos.

Por sua vez, o processo endógeno é regido por uma condição de mercado (condição (a)) dependente da taxa de juros de mercado. Deste modo, o 
parâmetro da distribuição de Poisson assume valor nulo, caso a condição racional não seja satisfeita, e valor positivo, caso a condição seja satisfeita. Assim, o processo endógeno satisfaz a condição necessária mas não suficiente do incentivo financeiro.

\subsection{Descrição do Modelo de Pré-pagamento}

Esta pesquisa baseia-se no modelo de fatores exógenos para explicar o pré-pagamento dos contratos de crédito imobiliário.

A motivação principal para a escolha do modelo é que não há evidência de incentivos financeiros aos mutuários que antecipem o pagamento de seus contratos. Ou seja, o mercado brasileiro não permite que fatores endógenos rejam o comportamento dos mutuários, de maneira que toda e qualquer decisão de pré-pagamento seja motivada por fatores exógenos. As principais evidências para não existência de fatores endógenos são:

\section{Mercado Regulamentado}

O mercado imobiliário brasileiro é altamente regulamentado pelo Banco Central do Brasil. As taxas de juros incidentes nos empréstimos imobiliários são, usualmente, abaixo das taxas observadas na economia. São conhecidas como taxas administradas. O Governo federal garante aos agentes econômicos a aplicação em poupança. Em contrapartida, as instituições financeiras devem compulsoriamente direcionar uma parte destas captações a empréstimos imobiliários, forçando-os a exercer taxas subsidiadas.

\footnotetext{
${ }^{21}$ Green e Shoven foram pioneiros na aplicação de processos de Poisson a modelos de prépagamento.
} 


\section{Inexistência de Mercado Secundário}

Não existe mercado secundário para empréstimos imobiliários, impedindo o refinanciamento da dívida por outra instituição financeira a taxas mais baixas.

\section{Altos Custos Transacionais}

Os custos transacionais sobre abertura de conta, abertura de crédito, etc., impedem que o mutuário recorra à outra instituição e adquira novo empréstimo, de modo que a condição de benefício financeiro nunca seja exercida.

\section{Limite de Recursos Disponíveis}

Há uma grande limitação de recursos que o sistema financeiro direciona ao mercado de crédito imobiliário. A demanda por empréstimos excede sua oferta.

As evidências acima afetam de duas maneiras a existência de fatores endógenos de pré-pagamento. Primeiramente de forma direta, a inexistência de mercado secundário e o limitado volume de recursos direcionados ao mercado imobiliário, de fato impedem a existência de uma estratégia ótima de pré-pagamento, ou de forma indireta, relacionada aos altos custos transacionais. Elevados custos transacionais têm um efeito redutor no preço da opção de compra dos mutuários, por aumentarem significativamente seu preço de exercício. Como citado anteriormente (p. 26) o preço de exercício da opção em poder do mutuário é $B_{l}^{P} \cdot\left(1+X_{1}\right)$, onde $X_{1}$ é o conjunto de todos os custos de transação, dado que, a relação entre o valor da opção e $X$, é positiva, direta e homogênea, o preço de exercício da opção é sempre muito elevado, o que as caracteriza como "opções fora do dinheiro".

Apesar das evidências mostrarem que não há formas do mutuário adquirir qualquer benefício financeiro, pré-pagamentos em empréstimos imobiliários são corriqueiramente observados na economia brasileira. Se não existe uma motivação econômica racional, outras razões não financeiras levam 
os mutuários a antecipar pagamentos. Novamente, o racional por trás dos prépagamentos não está no escopo desta pesquisa. Apenas algumas, talvez as mais óbvias, das possíveis razões serão enumeradas, a fim de situar o modelo no contexto econômico brasileiro. São eles:

\section{Uso do FGTS}

Só há duas maneiras de utilizar os recursos depositados no Fundo de Garantia por Tempo de Serviço (FGTS), ou quando da aposentadoria do contribuinte, ou para o contribuinte comprar sua casa própria ${ }^{22}$. Os recursos depositados são remunerados a TR (Taxa Referencial) acrescidos de três por cento ao ano, historicamente muito abaixo das aplicações no mercado. Durante o período do contrato de empréstimo imobiliário, ao mutuário faculta-se o direito de sacar seus recursos depositados a cada dois anos.

\section{Fatores Culturais}

O consumidor brasileiro não se caracteriza pelo seu alto nível de endividamento. Culturalmente, pessoas endividadas desejam liquidar seus compromissos o mais breve possível.

\section{Incerteza Econômica}

Até o presente, o Brasil jamais presenciou um longo período de estabilidade econômica e monetária, usufruiu baixas taxas de juros ou grande oferta de crédito. Medidas econômicas radicais, como aprisionamento de recursos (1989), foram vividas. Este fator influencia diretamente $\mathrm{o}$ item anterior.

Tais possíveis fatores são de ordem exógena. Modelar estes eventos condicionados a variáveis de mercado independentes demandaria um profundo estudo dos pré-pagamentos observados e conjuntura econômica. 


\section{O Modelo Exógeno}

Observações empíricas têm mostrado que os pré-pagamentos ocorrem em períodos concentrados ao longo da vida do contrato. Assim, a probabilidade de ocorrência do evento, em um período $\Delta t$ qualquer, depende do instante corrente do contrato. Um exemplo recente de literatura em modelos empíricos de pré-pagamentos que capturam esse evento é Schwartz e Torous (1989).

Especialmente por essa razão, o processo mais apropriado para modelar eventos de pré-pagamentos é o processo de Poisson não homogêneo, detalhado a seguir.

Neste modelo, a probabilidade de ocorrência de um prépagamento exógena é descrita por um processo de Poisson ${ }^{23} \mathrm{com}$ intensidade $\lambda=\left\{\lambda_{t}\right\}, t \geq 0$. A probabilidade do evento de pré-pagamento em um intervalo de tempo $\Delta t$, não condicionado a ocorrência de pré-pagamento anterior a $t$, é aproximadamente $\lambda_{t} \Delta t$, quando $\Delta t \cong 0$, o que quer dizer:

$$
P(t<\tau<t+\Delta t / \tau>t)=1-e^{-\tau+\Delta t_{d} d s}
$$

onde $\lambda_{t}$ é uma função $t \mapsto \lambda_{t}$ descrevendo a probabilidade instantânea de pré-pagamento, pois, para $\Delta t<<1$, pode-se assumir, sem perda de precisão que $\lambda_{t}$ é constante no intervalo $[t, t+\Delta t]$ e expandindo-se em Taylor $^{24}$, tem-se, que

$$
P(t<\tau<t+\Delta t / \tau<\Delta t)=\lambda_{t} \Delta t
$$

\footnotetext{
${ }^{22}$ Há restrições. Para detalhes sobre condições de saque do FGTS, consultar site www.fgtsfacil.com.br.

${ }^{23}$ Processos de Poisson, ou hazard functions são discutidos em detalhes em Kalbfleisch and Prentice (1980).

${ }^{24}$ Referente a expansão local de funções pelo método de Taylor.
} 
Em um processo de Poisson homogêneo, a função de intensidade $\lambda_{t}$ é constante $\lambda_{t}=\lambda$ e a probabilidade de ocorrência de um evento em certo $\Delta t$, não condicionado a sua ocorrência anterior a $t$, é aproximadamente $\lambda \Delta t$. De maneira prática, significa que a probabilidade de ocorrência do evento em $\Delta t$ a mesma em qualquer instante de tempo.

Surge, imediatamente, uma crítica importante a aplicação de processos de distribuição de probabilidades homogêneas na modelagem de eventos de pré-pagamentos em contratos de empréstimos imobiliários.

Quando consideramos $t=0$ e $T=t+\Delta t$, então a probabilidade condicional coincide com a probabilidade precondicional e obtemos a função de distribuição cumulativa $P(\tau<T)$ do tempo de pré-pagamento:

$$
P(\tau<T)=1-e^{-\int_{0}^{T} \lambda_{r} d t}
$$

Derivando a equação acima em relação à $T$, obtemos a densidade de probabilidade da variável aleatória $\tau$, denotada por $f(t)$, como segue:

$$
f(t)=\frac{\partial P(\tau<T)}{\partial T} /_{T=t}=\lambda_{t} \cdot e^{-\int^{j} \lambda_{d} d s}
$$

Com isto, podemos calcular o tempo médio $\bar{\tau}=E[\tau]$ de ocorrência do evento de pré-pagamento, como segue:

$$
\bar{\tau}=E[\tau]=\int_{0}^{T} t \cdot f(t) d t=\int_{0}^{T} t \cdot \lambda_{t} \cdot e^{-\int_{0}^{j} \lambda_{s} d s} d t
$$




\subsection{Cálculo do Fluxo de Pagamento Ajustado ao Risco}

A existência de um saldo $B_{l}^{P}$ em qualquer instante de tempo $0<t<T$ determina o valor pelo qual o detentor do passivo, o financiado, pode liquidá-lo antecipadamente ao vencimento da operação. De fato, como já discutido extensivamente, não há restrição contratual alguma que indique a impossibilidade de fazê-lo, ao contrário, há leis que expressamente garantem o direito, ou a opção, ao financiado de antecipar pagamentos ou até liquidar o contrato quando bem entender.

Esse evento exerce um grande efeito na estrutura de fluxo de pagamento do contrato descrito na seção 3. A partir da existência de antecipações, fluxos de caixa aleatórios incrementam a estrutura do contrato. A figura (2) ilustra esta ocorrência.

A figura (2) mostra um pré-pagamento parcial de um contrato de empréstimo imobiliário. A liquidação antecipada poderia ser total, caso este em que os fluxos de caixa posteriores à antecipação não existiriam.

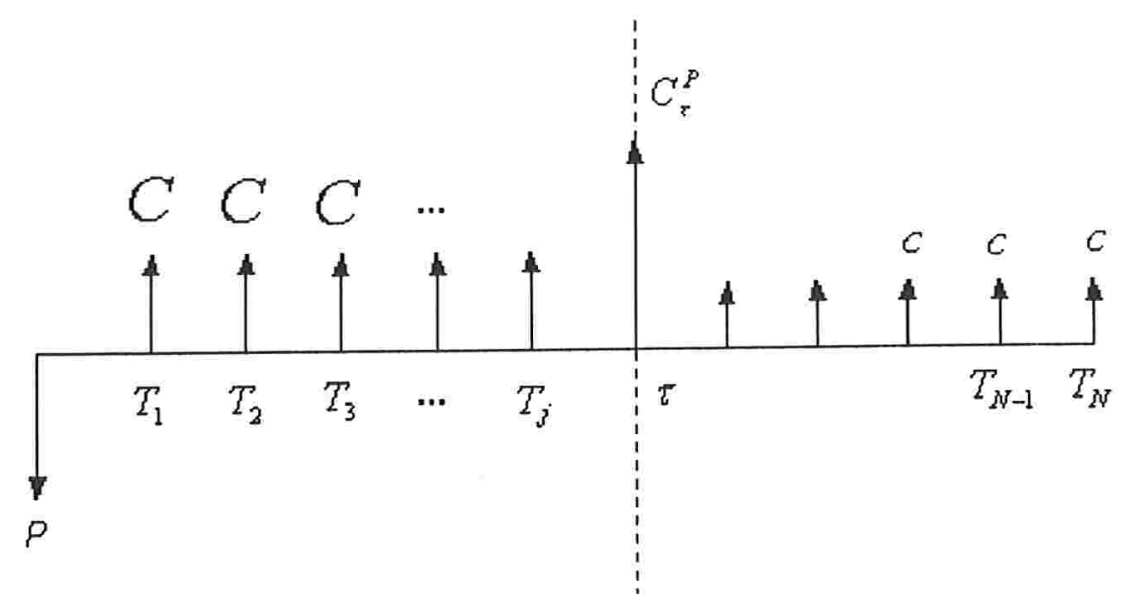

figura(2) 
Fica claro que a estrutura de fluxos de caixa sofre, na presença de pré-pagamentos, uma grande modificação. A natureza dessa modificação está relacionada à incerteza do tempo e volume de ocorrência do processo de prépagamento. Por alterar a estrutura de fluxos, os principais impactos das antecipações ocorrem no valor do contrato e conseqüentemente no spread esperado. A equação (5) define o valor em $t=0$ de $B_{0}^{P}$, como:

$$
B_{0}^{P}=\sum_{j=0}^{N} C \cdot e^{-\int_{0}^{T_{j}} r(s) d s}
$$

Para simplificar a representação matemática de $B_{0}^{P}$, os fatores de

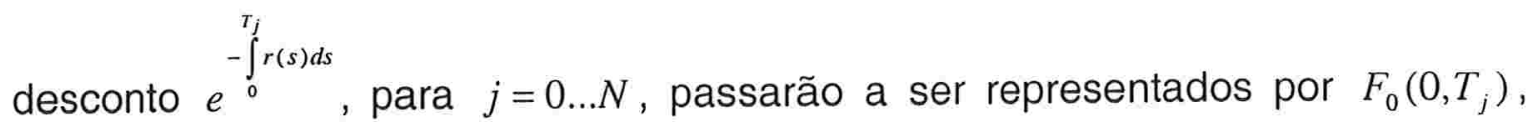
isto é:

$$
F_{0}\left(0, T_{j}\right)=e^{-\int_{0}^{T_{j}}(s) d s}
$$

de modo que:

$$
B_{0}^{P}=\sum_{j=0}^{N} C \cdot F_{0}\left(0, T_{j}\right)
$$

Vamos supor que o momento $\tau$ onde ocorre o pré-pagamento fosse conhecido a priori e que neste instante de tempo ocorresse uma antecipação de pagamento $C_{j}^{P}$. É importante ressaltar que este modelo pressupõe a ocorrência de apenas um evento de pré-pagamento durante a vida do contrato.

O valor de $B_{0}^{P}$, ou $P$, passa a ser definido como: 


$$
B_{0}^{P}=P=C \cdot \sum_{j=0}^{\tau-1} F_{0}\left(0, T_{j}\right)+C_{\tau}^{P} \cdot F_{0}\left(0, T_{\tau}\right)+c \cdot \sum_{j=\tau+1}^{N} F_{0}\left(0, T_{j}\right)
$$

onde, $c$ denota o valor dos fluxos de caixa gerados a partir de (3) (ver figura (2)).

O fluxo de caixa $C_{\tau}^{P}$ está representado, até o momento, em unidades monetárias. Contudo, para qualquer $0<\tau<T$ pode ser representado por um percentual, denominado $\delta_{\tau}$, do saldo da dívida total no instante $\tau$.

Por (5), $B_{t}^{P}$ pode ser calculado para qualquer $0 \leq t \leq T$. Isto implica que pode-se representar $C_{\tau}^{P}$, por:

$$
C_{\tau}^{P}=\delta_{\tau} \cdot C \sum_{j=\tau}^{N} F_{\tau}\left(\tau, T_{j}\right)
$$

Por (21) nota-se que, como já mencionado, o evento $C_{\tau}^{P}$ está condicionado ao instante de tempo $\tau$.

Substituindo-se (21) em (20) e considerando a incerteza de tempo de ocorrência do evento de pré-pagamento, temos:

$$
P=E\left[B_{0}^{P}\right]=E\left[C \cdot \sum_{j=0}^{\tau-1} F_{0}\left(0, T_{j}\right)+\left[\delta_{\tau} \cdot C \sum_{j=\tau}^{N} F_{\tau}\left(\tau, T_{j}\right)\right] \cdot F_{0}\left(0, T_{\tau}\right)+c \cdot \sum_{j=\tau+1}^{N} F_{0}\left(0, T_{j}\right)\right]
$$

O momento $t=\tau$ é um evento determinante do valor de $B_{0}^{P}$. Ele divide os fluxos de pagamentos do instrumento em três períodos distintos ao longo de sua vida: anteriores ao pré-pagamento, o pré-pagamento em si e posteriores ao pré-pagamento. A ocorrência de $C_{\tau}^{P}$ transforma um instrumento, antes composto por uma série de fluxos de pagamento regulares em prazo e volume, em um instrumento de fluxos de pagamento irregulares. Lembramos 
mais uma vez que, neste estudo que $C_{\tau}^{P}$ ocorre uma única vez ao longo da vida do contrato, em qualquer $t=\tau$, e de volume desconhecido, $\delta_{\tau} \cdot B_{\tau}^{P}$. Caso $\delta_{\tau}=1$, ocorre o evento de pré-pagamento total e determina o fim do contrato.

O pré-pagamento do contrato é um fluxo de caixa de volume desconhecido e tempo inesperado, que ocorre em determinados estados da natureza. Seguindo um rigor matemático, esses eventos são chamados de contingentes e a eles podem ser atribuídas probabilidades.

Para representar precisamente o valor de $B_{0}^{P}$, os fluxos de caixa do instrumento devem apresentar suas respectivas probabilidades de ocorrência, conforme:

Seja $I_{A}$ a função indicadora do evento $A$, se:

$$
\left\{\begin{array}{l}
I_{A}=1, \text { se o evento } A \text { ocorre } \\
I_{A}=0, \text { se o evento } A \text { não ocorre }
\end{array}\right.
$$

$$
E\left[B_{0}^{P}\right]=E\left[\sum_{j=0}^{N} C \cdot \mathrm{I}_{\left\{\tau>T_{j}\right\}} \cdot F_{0}\left(0, T_{j}\right)+\delta_{\tau} \cdot B_{\tau}^{P} \cdot F_{0}\left(0, T_{\tau}\right)+\sum_{j=0}^{N} c \cdot \mathrm{I}_{\left\{\tau<T_{j}\right\}} \cdot F_{0}\left(0, T_{j}\right)\right]
$$

A equação (23) acima, descreve precisamente o comportamento dos fluxos de caixa do título $B_{0}^{P}$, ponto de partida para o cálculo de seu valor justo. Retomando-se a condição da equação (4), tem-se que $E\left[B_{0}^{P}-V_{0}^{A}\right]=0$, que impõe igualdade entre a taxa do instrumento e a estrutura temporal das taxas de juros de mercado na ausência de spread, o que significa que $E\left[B_{0}^{P}\right]=E\left[V_{0}^{A}\right]=P$. Esta relação define que na ausência de spread, o valor do saldo do contrato e o valor de mercado são iguais ao principal entregue ao financiado. É importante destacar que na prática essa relação só é verdadeira no instante da execução do negócio, uma vez que as taxas de mercado comportam-se de forma instável, 
flutuando constantemente. Aplicando a relação a equação (23), tem-se a nova equação de valor justo de mercado para $B_{0}^{P}$ :

$$
E\left[V_{0}^{A}\right]=E\left[\sum_{j=0}^{N} C \cdot \mathrm{I}_{\left\{\tau>T_{j}\right\}} \cdot e^{-\int_{i_{j}(s) d s}^{\tau_{j}}}+\left[\delta_{\tau} \cdot C \sum_{j=\tau}^{N} e^{-\int_{j}^{T_{j}} r(s) d s}\right] \cdot e^{-\int_{i}^{j_{\tau}(s) d s}}+\sum_{j=0}^{N} c \cdot \mathrm{I}_{\left\{\left\{<T_{j}\right\}\right.} \cdot e^{\left.-\int_{j}^{\tau_{j}(s) d s}\right]}\right.
$$

Para simplificar novamente a notação matemática, os fatores de

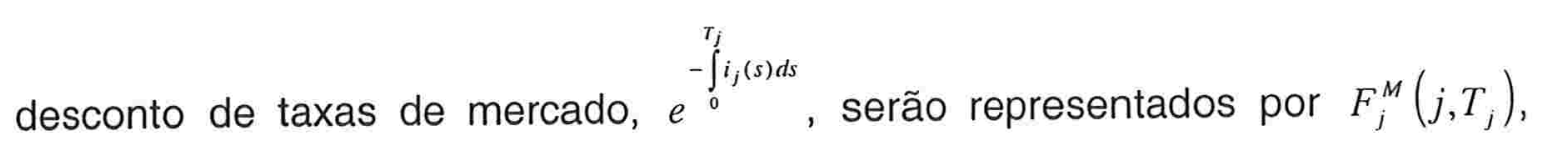
para $j=0 \ldots N$. Assim, simplificando a equação (24) e aplicando-a a definição de (18), tem-se a seguinte equação:

$$
E\left[V_{0}^{A}\right]=E\left[C \cdot \sum_{j=0}^{N} \mathrm{I}_{\left\{\tau>T_{j}\right\}} \cdot F_{0}^{M}\left(0, T_{j}\right)+\left[\delta_{\tau} \cdot B_{\tau}^{P}\right] \cdot F_{0}^{M}(0, \tau)+c \cdot \sum_{j=0}^{N} \mathrm{I}_{\left\{\tau<T_{j}\right\}} \cdot F_{0}^{M}\left(0, T_{j}\right)\right]
$$

A equação acima define o valor de mercado do ativo sob a ótica do financiador. A estrutura de fluxos de caixa do contrato passa a depender agora da probabilidade de ocorrência do fluxo de pré-pagamento e do volume prépago, que por sua vez são dependentes do tempo. A dependência de $B_{t}^{P}$ e $V_{l}^{A}$ podem ser expressas em relação a suas variáveis independentes, como:

$$
f\left[\mathrm{I}_{A}(t), \delta(t)\right]
$$

Esta notação expressa de maneira simplificada a relação de dependência do preço de um contrato de empréstimo que possua a opção de pré-pagamento pela sua taxa de juros original. De fato, as formulações matemáticas até o momento tentam traduzir o comportamento humano do 
financiado, o detentor do passivo. Contudo, as razões por trás deste comportamento não fazem parte do objetivo desta pesquisa.

Ao isolarmos os termos determinísticos em (25), obtemos:

$$
E\left[V_{0}^{A}\right]=C \cdot E\left[\sum_{j=0}^{N} \mathrm{I}_{\left\{\tau>T_{j}\right\}} \cdot F_{0}^{M}\left(0, T_{j}\right)\right]+E\left[\delta_{\tau} B_{\tau}^{P} \cdot F_{0}^{M}(0, \tau)\right]+c \cdot E\left[\sum_{j=0}^{N} \mathrm{I}_{\left\{\tau<T_{j}\right\}} \cdot F_{0}^{M}\left(0, T_{j}\right)\right]
$$

Ao explicitar as probabilidades de ocorrência de pré-pagamento a equação (26), obtém-se uma representação bastante intuitiva do comportamento dos fluxos de caixa do contrato em questão:

$$
E\left[V_{0}^{A}\right]=C \cdot \sum_{j=0}^{N} P\left(\tau>T_{j}\right) \cdot F_{0}^{M}\left(0, T_{j}\right)+E\left[\delta_{\tau} B_{\tau}^{P} \cdot F_{0}^{M}(0, \tau)\right]+c \cdot \sum_{j=0}^{N} P\left(\tau<T_{j}\right) \cdot F_{0}^{M}\left(0, T_{j}\right)
$$

Seguindo a condição (a) existente na ausência de spread, hipótese adotada até o momento, e colocando $c$ em evidência na equação (27), tem-se:

$$
c=\frac{P-C \cdot \sum_{j=0}^{N} P\left(\tau>T_{j}\right) \cdot F_{0}^{M}\left(0, T_{j}\right)-E\left[\delta_{\tau} \cdot B_{\tau}^{P} \cdot F_{0}^{M}(0, \tau)\right]}{\sum_{j=0}^{N} P\left(\tau<T_{j}\right) \cdot F_{0}^{M}\left(0, T_{j}\right)}
$$

A equação (28) exprime o valor do fluxo de caixa futuro após a ocorrência do pré-pagamento. A solução desta equação é o fator principal para cálculo do valor justo de mercado do contrato de empréstimo. O valor do contrato é determinado pelo valor presente de todos seus fluxos de pagamentos futuros. O conjunto de fluxos de pagamento pode, de forma simplificada, ser dividido em dois subconjuntos, os de fluxos de pagamento anteriores e os posteriores ao evento de pré-pagamento. Toda elaboração do problema até este ponto, deixa claro que a incerteza recai sobre o pré-pagamento e a seus fluxos 
posteriores subseqüentes. A solução de $c$ é importante parte do objetivo desta pesquisa.

Inserindo a relação entre $O$ valor principal $P$ e os fluxos de pagamento não ajustados ao risco $P=C \cdot \sum_{j=0}^{N} F_{0}^{M}\left(0, T_{j}\right)$ e a relação vigente no instante de pré-pagamento entre o saldo remanescente e os valores dos mesmos fluxos de pagamento $B_{\tau}^{P}=\sum_{j=\tau}^{N} C \cdot F_{\tau}\left(\tau, T_{j}\right)$, obtemos uma relação fundamental entre os valores dos fluxos de pagamento:

$$
c=C \cdot \frac{\left[\sum_{j=0}^{N}\left(1-P\left(\tau>T_{j}\right)\right) \cdot F_{0}^{M}\left(0, T_{j}\right)-E\left[\delta_{\tau} \sum_{j=\tau}^{N} F_{\tau}\left(\tau, T_{j}\right) \cdot F_{0}^{M}(0, \tau)\right]\right]}{\sum_{j=0}^{N} P\left(\tau<T_{j}\right) \cdot F_{0}^{M}\left(0, T_{j}\right)}
$$

A equação (29) acima declara um fluxo contingente, $c$, como função de um fluxo determinado no início do contrato, $C$, multiplicado por um fator de ajuste ao risco de pré-pagamento $\Gamma$. Pode-se dizer assim, que a equação (29) define o valor da parcela $c$ como a parcela $C$ ajustada ao risco de pré-pagamento.

$$
\Gamma=\frac{\left[\sum_{j=0}^{N}\left(1-P\left(\tau>T_{j}\right)\right) \cdot F_{0}^{M}\left(0, T_{j}\right)-E\left[\delta_{\tau} \sum_{j=\tau}^{N} F_{\tau}\left(\tau, T_{j}\right) \cdot F_{0}^{M}(0, \tau)\right]\right]}{\sum_{j=0}^{N} P\left(\tau<T_{j}\right) \cdot F_{0}{ }^{M}\left(0, T_{j}\right)}
$$


O modelo distingue os três períodos da vida do contrato - antes da ocorrência do pré-pagamento, o evento em si e após sua ocorrência determinantes ao seu valor justo, considerando suas respectivas probabilidades de ocorrência.

$\mathrm{Na}$ seção 4.3. foi descrito o processo de distribuição de probabilidade associado ao tempo de ocorrência dos eventos de prépagamento, o processo de Poisson não homogêneo.

A equação (27) define o valor justo de um contrato de crédito imobiliário, conforme:

$$
\begin{aligned}
E\left[V_{0}^{A}\right] & =C \cdot \sum_{j=0}^{N} P\left(\tau>T_{j}\right) \cdot F_{0}^{M}\left(0, T_{j}\right)+E\left[\delta_{\tau} B_{\tau}^{P} \cdot F_{0}^{M}(0, \tau)\right]+c \cdot \sum_{j=0}^{N} P\left(\tau<T_{j}\right) \cdot F_{0}^{M}\left(0, T_{j}\right) \\
& =\mathrm{I}+\mathrm{II}+\mathrm{III}
\end{aligned}
$$

A equação (27) acima, pode ser representada como a soma de três eventos contingentes independentes I, II e III :

A fim de facilitar a apresentação dos resultados, cada probabilidade será calculada individualmente, de acordo com a definição das partes abaixo:

a) Parcelas pagas anteriores ao instante de pré-pagamento:

$$
\mathrm{I}=C \cdot \sum_{j=0}^{N} P\left(\tau>T_{j}\right) \cdot F_{0}^{M}\left(0, T_{j}\right)
$$

pelo processo de Poisson não homogêneo, tem-se diretamente que:

$$
P\left(\tau>T_{j}\right)=1-P\left(\tau<T_{j}\right)=e^{-\int_{0}^{T_{j}} \lambda_{t} d t}
$$


e substituindo (33) em a), obtém-se o resultado:

$$
\mathrm{I}=C \cdot \sum_{j=0}^{N} e^{-\int_{0}^{T_{j}} \lambda_{t} d t} \cdot F_{0}^{M}\left(0, T_{j}\right)
$$

b) Adiantamento da dívida (termo de pré-pagamento):

$$
\mathrm{II}=E\left[\delta_{\tau} B_{\tau}^{P} \cdot F_{0}^{M}(0, \tau)\right]
$$

Usando a definição de $C_{\tau}^{P}$ conforme a equação (21), tem-se:

$$
\begin{aligned}
& \mathrm{II}=E\left[\delta_{\tau} B_{\tau}^{P} \cdot F_{0}^{M}(0, \tau)\right]=C \cdot \sum_{j=0}^{N} E\left[\delta_{\tau} \cdot \mathrm{I}_{\left\{\tau_{j}>\tau\right\}} \cdot e^{-\int_{\tau}^{T_{s}} r_{s} d s} \cdot e^{-\int_{0}^{\tau} i_{s} d s}\right] \\
& =C \cdot \sum_{j=0}^{N} E\left[\delta_{\tau} \cdot \mathrm{I}_{\left\{T_{j}>\tau\right\}} \cdot e^{-\int_{0}^{T_{j}} r_{s} d s} \cdot e^{\int_{0}^{\tau} r_{s} d s} \cdot e^{-\int_{0}^{\tau} i_{s} d s}\right] \\
& =C \cdot \sum_{j=0}^{N} e^{-\int_{0}^{r_{j}} r_{s} d s} \cdot E\left[\delta_{\tau} \cdot \mathrm{I}_{\left\{T_{j}>\tau\right\}} \cdot e^{\int_{0}^{\tau}\left(r_{s}-i_{s}\right) d s}\right] \\
& =C \cdot \sum_{j=0}^{N} e^{-\int_{0}^{T_{j}} r_{s} d s} \cdot P\left(\tau<T_{j}\right) \cdot \int_{0}^{T_{j}} e^{\int_{0}\left(r_{s}-i_{s}\right) d s} \cdot P(\tau=t) \cdot \delta_{t} \cdot d t \\
& =C \cdot \sum_{j=0}^{N} e^{-\int_{0}^{T_{j}} r_{s} d s} \cdot\left(1-e^{-\int_{0}^{r_{j}} \lambda_{t} d t}\right) \cdot \int_{0}^{T_{j}} e^{\int_{0}\left(r_{s}-i_{s}\right) d s} \cdot \lambda_{t} \cdot e^{-\int_{0}^{1} \lambda_{s} d s} \cdot \delta_{t} \cdot d t
\end{aligned}
$$


c) Parcelas pagas após o pré-pagamento:

$$
\mathrm{III}=c \cdot \sum_{j=0}^{N} P\left(\tau<T_{j}\right) \cdot F_{0}^{M}\left(0, T_{j}\right)
$$

Novamente, aplicando-se diretamente a definição de Poisson, temos que,

$$
P\left(\tau<T_{j}\right)=1-e^{-\int_{0}^{T_{j}} \lambda_{t} d t}
$$

e portanto:

$$
\mathrm{III}=c \cdot \sum_{j=0}^{N}\left(1-e^{-\int_{0}^{T_{j}} \lambda_{t} d t}\right) \cdot F_{0}^{M}\left(0, T_{j}\right)
$$

Por fim, concatenando-se os resultados de (a), (b) e (c), temos: 


$$
\begin{aligned}
V_{0}^{A}= & C \cdot \sum_{j=0}^{N} e^{-\int_{0}^{T_{j}} \lambda_{t} d t} \cdot F_{0}^{M}\left(0, T_{j}\right) \\
& +e^{-\int_{0}^{T_{j}} r_{s} d s} \cdot\left(1-e^{\int_{0}^{T_{j}} \lambda_{t} d t}\right) \cdot \int_{0}^{T_{j}} e^{\int_{0}\left(r_{s}-i_{s}\right) d s} \cdot \lambda_{t} \cdot e^{-\int_{0}^{1} \lambda_{s} d s} \cdot \delta_{t} \cdot d t \\
& +c \cdot \sum_{j=0}^{N}\left(1-e^{\left.-\int_{0}^{T_{j} \lambda_{t} d t}\right) \cdot F_{0}^{M}\left(0, T_{j}\right)}\right.
\end{aligned}
$$

Desta fórmula é possível extrair o valor $c$ da parcela, calculada posteriormente ao fluxo de pré-pagamento.

\subsection{Calibração do Modelo}

A apresentação do processo de Poisson não homogêneo, feita no seção 4.3. que descreve o modelo utilizado nesta pesquisa, mostrou que o processo $\lambda_{t}$ é responsável por determinar a intensidade da probabilidade de ocorrência de certo evento em um determinado espaço de tempo. O processo $\lambda_{t}$, então, é o parâmetro fundamental para solucionar o modelo de prépagamento, aqui proposto. Ressalta-se que a proposição que os eventos prépagamentos são regidos por fatores exógenos possibilita a extração dos parâmetros de distribuição de observações empíricas. Seguindo essa proposição, o conjunto de dados observados de freqüência de eventos de prépagamentos é a fonte de extração dos parâmetros $\lambda_{1}$, conforme elaborado abaixo. Para isto, vamos assumir que o processo $\left\{\lambda_{t}\right\}$ é constante por partes ao longo do tempo da vida do contrato. Assumimos que

$$
\lambda_{t}=\lambda_{j} \text { para todo } T_{j-1} \leq t \leq T_{j} .
$$


A equação (13) define:

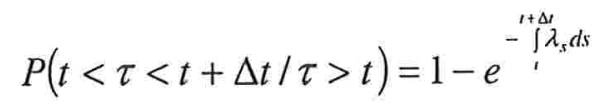

Para todo $j=1,2, \ldots, N$, escrevemos:

$$
P\left(\tau \leq T_{j}\right)=1-e^{-\int_{j}^{\tau_{j}} \lambda_{s} d s} \text { e } P\left(\tau \leq T_{j}+\Delta t\right)=1-e^{-\int_{0}^{T_{j}+\Delta t} \lambda_{s} d s}
$$

Tomando o logaritmo e usando a linearidade da integral, temos que:

$$
\begin{aligned}
\operatorname{Ln}\left[1-P\left(\tau \leq T_{j}+\Delta t\right)\right] & =-\int_{0}^{T_{j}+\Delta t} \lambda_{t} d t \\
& =-\int_{0}^{T_{j}} \lambda_{t} d t-\int_{T_{j}}^{25} \lambda_{t} d t \\
& =\operatorname{Ln}\left[1-P\left(\tau \leq T_{j}\right)\right]-\int_{T_{j}}^{T_{j}+\Delta t} \lambda_{t} d t
\end{aligned}
$$

Logo:

$$
\begin{aligned}
\int_{T_{j}}^{T_{j}+\Delta t} \lambda_{t} d t & =\operatorname{Ln}\left[1-P\left(\tau \leq T_{j}\right)\right]-\operatorname{Ln}\left[1-P\left(\tau \leq T_{j}+\Delta t\right)\right] \\
& =\operatorname{Ln}\left[\frac{1-P\left(\tau \leq T_{j}\right)}{1-P\left(\tau \leq T_{j}+\Delta t\right)}\right]
\end{aligned}
$$

Assumindo-se $\lambda_{t}$ constante em cada período $\Delta t^{26}$, então: 


$$
\lambda_{t} \int_{T_{j}}^{T_{j}+\Delta t} d t=\operatorname{Ln}\left[\frac{1-P\left(\tau \leq T_{j}\right)}{1-P\left(\tau \leq T_{j}+\Delta t\right)}\right]
$$

Os dados empíricos da base de dados de pré-pagamento foram observados pelo período de dez anos, subdivididos em meses (cento e vinte períodos). Com isso, a função contínua (48) pode ser discretizada para $\Delta t=1$ (mês).

$$
\begin{aligned}
& \lambda_{t} \sum_{N}^{N+1} \Delta t=\operatorname{Ln}\left[\frac{1-P\left(\tau \leq T_{j}\right)}{1-P\left(\tau \leq T_{j}+\Delta t\right)}\right] \\
& \lambda_{t}=\operatorname{Ln}\left[\frac{1-P\left(\tau \leq T_{j}\right)}{1-P\left(\tau \leq T_{j}+\Delta t\right)}\right]
\end{aligned}
$$

Por (50), a extração de cada parâmetro $\lambda_{t}$, de cada respectivo período $\Delta t$ é feita através das probabilidades de ocorrência do evento em $T_{j}$ e $T_{j}+\Delta t$, que pode ser representado por $T_{j+1}$. Como forma final de (50), tem-se:

$$
\lambda_{j}=\operatorname{Ln}\left[\frac{1-P\left(\tau \leq T_{j}\right)}{1-P\left(\tau \leq T_{j+1}\right)}\right]
$$

Da base de dados, as probabilidades são representadas pela freqüência observada de pré-pagamentos.

\footnotetext{
${ }^{25}$ Ln é o logaritmo natural de base $e$.

${ }^{26}$ Conforme seção 4.3., p.34.
} 
A freqüência $f q_{j}$ de pré-pagamentos é extraída da quantidade $M_{j}$ de mutuários que efetuaram pré-pagamentos em determinado período $j$, pelo total de mutuários $T M$ da carteira.

$$
f q_{j}=\frac{\sum M_{j}}{T M}
$$

Contudo, as freqüências extraídas são referentes a cada período e as probabilidades usadas na obtenção dos parâmetros $\lambda_{j}$ são do tempo inicial a cada tempo $T_{j}\left(T_{j}=j \cdot \Delta t\right)$. Para tal, as freqüências observadas em cada período foram acumuladas, conforme:

$$
F_{k}=\sum_{j=1}^{k} f q_{j}
$$

onde,

$F_{k}=$ freqüência acumulada até o período $k$.

$f q_{j}=$ freqüência observada no período $j$.

O outro parâmetro do modelo extraído da base de dados é o volume de pré-pagamento de cada evento de pré-pagamento. O volume percentual $\delta_{j}$ é a somatória dos volumes dos fluxos de pré-pagamento $C_{j}^{p}$ ocorridos em determinado período $j$ dividido pela soma dos respectivos saldos dos contratos $B_{j}^{P}$ pré-pagos.

$$
\delta_{j}=\frac{\sum C_{j}^{p}}{\sum B_{j}^{p}}
$$




\section{RESULTADOS}

\subsection{Descrição Dados Utilizados}

Os dados observados nesta pesquisa são fictícios, mas guardam fidelidade ao formato de dados extraídos de bases reais. Com isso, esta pesquisa pode ser facilmente replicada com um conjunto de dados reais.

Como fonte para a extração dos parâmetros serão utilizados cem contratos de empréstimos imobiliários simulados. Cada contrato apresentará um evento de pré-pagamento arbitrado no tempo de maneira a concentrá-los próximos à metade da vida dos contratos e em volume de forma aleatória, respeitando, assim, o comportamento esperado dos mutuários, que devem seguir as motivações relacionadas no capítulo anterior. Novamente, não é escopo desta pesquisa discutir as razões de existência de pré-pagamentos, mas sim de prover usuários de uma ferramenta de apreçamento, que se adeque a qualquer conjunto de dados extraído do mercado.

Os contratos foram simulados desde seu início até seu vencimento. Todos os contratos da base simulada tiveram seus prazos decorridos, que simulam uma base histórica de dados passados. Deste modo, é possível capturar o comportamento de todos os mutuários do início de seu financiamento até a sua liquidação total. É importante relacionar o conjunto de premissas, ou hipóteses, usado na criação desta base de dados:

1. Todos os contratos iniciam e vencem no mesmo dia, ou seja, têm o mesmo período de duração. Desta forma, mantém-se a homogeneidade dos contratos (todos os mutuários testemunham as mesmas alterações nas conjunturas econômicas). O prazo dos contratos é de dez anos.

2. Os volumes foram determinados, aleatoriamente, com ponto de partida em 50.000,00. 
3. Os contratos só podem apresentar um evento de prépagamento durante sua vida.

4. Os eventos de pré-pagamentos foram escolhidos de modo a concentrar-se em torno da metade da vida dos contratos.

5. Os volumes de pré-pagamento foram escolhidos aleatoriamente e variam entre $0,1 \%$ à $100 \%$, este último representa a liquidação total antecipada do contrato.

Para se capturar todos os eventos de pré-pagamento em seus momentos mais próximos, a informação da evolução mensal de cada contrato deve ser observada. A freqüência mensal está relacionada com a característica do contrato de pagamentos programados mensais. É intuitivo deduzir que os eventos de pré-pagamentos concentram-se nas mesmas datas dos pagamentos programados. Como os parâmetros extraídos dos dados são mensais, mesmo com a ocorrência de um evento entre datas de pagamentos programados, esta será capturada na observação mensal subseqüente, sem causar perda de precisão ao modelo.

Os dados necessários disponíveis na base de dados estão relacionados abaixo, conforme a tabela (1): 


\begin{tabular}{|c|c|l|l|}
\cline { 2 - 4 } \multicolumn{1}{c|}{} & Numero do Contrato & & \\
\cline { 2 - 4 } \multicolumn{1}{c|}{} & Principal & & \\
\hline & Data de Início & & \\
\hline & Deata de Vencimento & & \\
\hline \multirow{4}{*}{$\begin{array}{c}\text { Período em } \\
\text { meses }\end{array}$} & Taxa de Juros & & \\
\hline & Valor da Parcela & & \\
\hline & Amortização de Juros & & \\
\cline { 2 - 4 } & Amortização de Principal & & \\
\cline { 2 - 4 } & Valor de Pré-pagamento & & \\
\hline & Saldo do Contrato & & \\
\hline \multirow{3}{*}{$2 \mathrm{M}$} & Amortização de Juros & & \\
\hline & Amortização de Principal & & \\
\hline & Valor de Pré-pagamento & & \\
\hline & Saldo do Contrato & & \\
\hline
\end{tabular}

tabela (1)

Numero do Contrato: número de referência do contrato.

Principal: valor inicial do contrato, $(P)$.

Data de Início: data da contratação do empréstimo.

Data de Vencimento: data de término do contrato. O número de períodos do contrato, $(N)$, é o número de meses entre Data de Início e Data de Vencimento.

Taxa de Juros: taxa de juros nominal do contrato, $(r)$.

Valor da Parcela: valor em de cada pagamento programado mensal, $(C)$.

Amortização de Juros: valor referente à amortização de juros em cada parcela mensal.

Amortização de Principal: valor referente à amortização de principal em cada parcela mensal.

Valor de Pré-pagamento: valor do pré-pagamento observado no respectivo mês.

Saldo do Contrato: novo saldo do contrato considerando a amortização efetuada no respectivo mês observado, seja esta com ou sem o evento de pré-pagamento. 
A tabela (1) é preenchida com os dados de cada contrato na horizontal (à direita) e sua respectiva evolução no tempo na vertical (à baixo).

Os dados do contrato são suficientes para calcular o fluxo de caixa de cada parcela e suas datas programadas. O pagamento de cada parcela ocorre no mesmo dia do início do contrato em cada mês subseqüente. O valor de cada parcela é calculado substituindo-se cada parâmetro da equação (1), por seus respectivos valores encontrados nos dados do contrato. Exemplo (extraído da base de dados):

Dados do contrato

\begin{tabular}{|c|c|}
\hline Número do Contrato & 10012345 \\
\hline Principal $(P)$ & $50.000,00$ \\
\hline Data de Início & $02 / 01 / 1990$ \\
\hline Data de Vencimento & $02 / 01 / 2000$ \\
\hline Taxa de Juros do contrato $(r)$ & $12,00 \%$ \\
\hline
\end{tabular}

De acordo com (2), tem-se:

$$
\begin{aligned}
& C=\frac{50.000,00}{\frac{(1+0,009488)^{120}-1}{0,009488 \cdot(1+0,009488)^{120}}} \\
& C=699,74
\end{aligned}
$$

onde,

$n=$ meses entre 02/01/1990 a 02/01/2000

$n=120$

$i=(1+0,12)^{(1 / 12)}-1$

$i=0.9488 \%$ 
Assim, o fluxo de caixa esperado na data de contratação do empréstimo, sem o efeito do pré-pagamento, está representado pelo gráfico (1) abaixo:

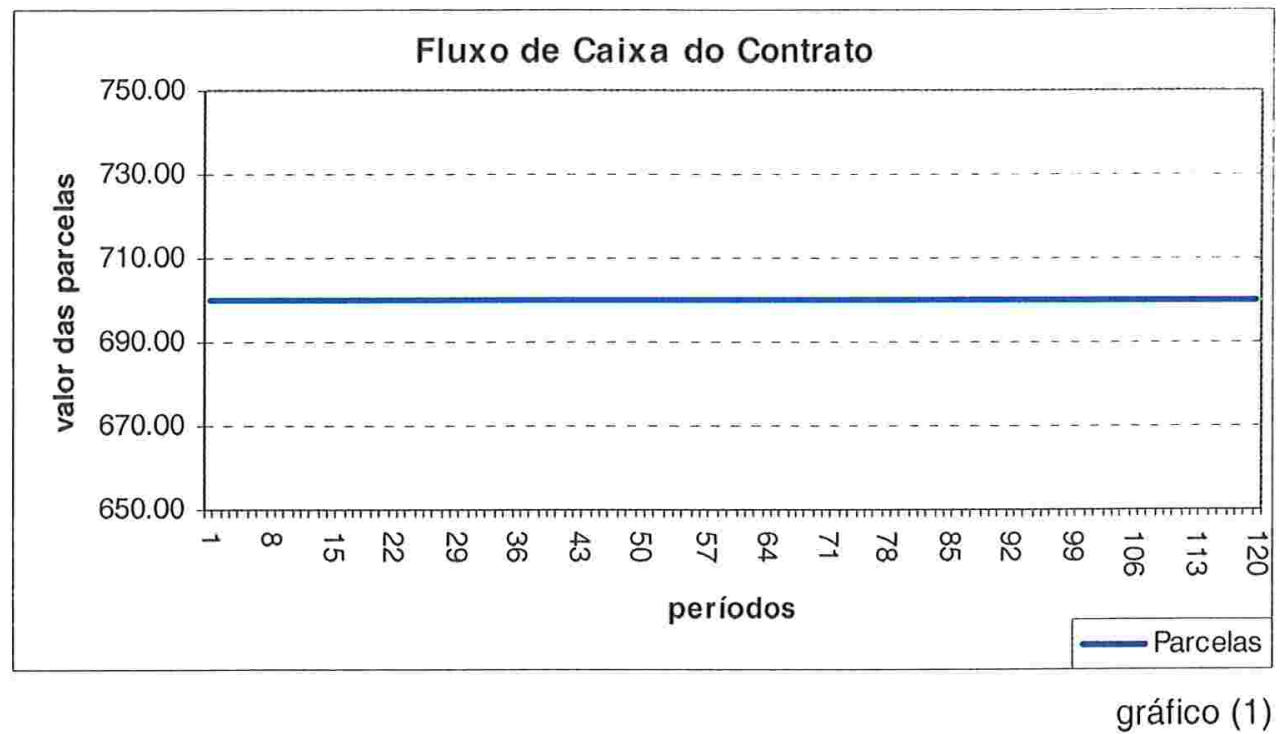

Os dados de evolução temporal do contrato proverão a informação da ocorrência do evento de pré-pagamento. Cada um dos fluxos de pagamento do contrato, $C$, amortiza uma parte dos juros e uma parte do principal, de acordo com o método de amortização estabelecido em contrato, nesta pesquisa os contratos têm parcelas constantes e amortização crescente.

O preenchimento dos dados de evolução temporal pode ser feito conforme o exemplo abaixo, seguindo os dados do mesmo contrato utilizado anteriormente: 
Dados de Evolução Temporal do Contrato - Período 1

\begin{tabular}{|c|c|c|}
\hline $\begin{array}{c}\text { Período em } \\
\text { meses }\end{array}$ & \multicolumn{2}{|c|}{} \\
\hline \multirow{3}{*}{$1 \mathrm{M}$} & Amortização de Juros $\left(A_{1}^{r}\right)$ & 474,44 \\
\cline { 2 - 3 } & Amortização de Principal $\left(A_{1}^{P}\right)$ & 225,30 \\
\cline { 2 - 3 } & Pré-pagamento $\left(C_{1}^{P}\right)$ & 0 \\
\cline { 2 - 3 } & Saldo Atual do Contrato $\left(B_{1}^{P}\right)$ & $49.774,70$ \\
\hline
\end{tabular}

tabela(3)

onde,

$A_{1}^{r}=B_{0}^{P} \cdot r$

como $B_{0}^{P}=P$, logo:

$A_{1}^{r}=50.000 \cdot 0,9488$

$A_{1}^{r}=474,44$

$A_{1}^{P}=C-A_{1}^{r}$

$A_{1}^{P}=699,74-474,44$

$A_{1}^{P}=225,30$

$B_{1}^{P}=B_{0}^{P}-A_{1}^{P}-C_{1}^{P}$

$B_{1}^{P}=50.000-225,30$

$B_{1}^{P}=49.774,70$

$C_{1}^{P}=0$, arbitrariamente. 
Define-se 0 valor de $C_{1}^{P}$ arbitrariamente por tratar-se de manipulação de dados fictícios. Tratando-se de base de dados real, $C_{1}^{P}>0$, se e somente se, ocorresse pré-pagamento, $C_{\text {observado }}>C_{\text {esperado }}$. Nesta situação, o valor de $C_{1}^{P}$ seria dado por $C_{\text {observado }}-C_{\text {esperado }}$, onde $C_{\text {esperado }}=C$ e $C=A_{1}^{r}+A_{1}^{P}$.

O mês subseqüente apresenta os seguintes dados de evolução, conforme tabela (4):

Dados de Evolução Temporal do Contrato - Período 2

\begin{tabular}{|c|c|c|}
\hline $\begin{array}{c}\text { Período em } \\
\text { meses }\end{array}$ & \multicolumn{2}{|c|}{} \\
\hline \multirow{3}{*}{$2 \mathrm{M}$} & Amortização de Juros $\left(A_{2}^{r}\right)$ & 472,30 \\
\cline { 2 - 3 } & Amortização de Principal $\left(A_{2}^{P}\right)$ & 227,43 \\
\cline { 2 - 3 } & Pré-pagamento $\left(C_{2}^{P}\right)$ & 0 \\
\cline { 2 - 3 } & Saldo Atual do Contrato $\left(B_{2}^{P}\right)$ & $49.547,47$ \\
\hline
\end{tabular}

tabela (4)

onde,

$$
\begin{aligned}
& A_{2}^{r}=B_{1}^{P} \cdot r \\
& A_{2}^{P}=C-A_{2}^{r} \\
& B_{2}^{P}=B_{1}^{P}-A_{2}^{P}-C_{2}^{P} \\
& C_{2}^{P}=0, \text { arbitrariamente }{ }^{27} .
\end{aligned}
$$

Nota-se que o resultado observado de $B_{2}^{P}$, da equação (60), é estritamente o mesmo resultado quando calculado pela equação (4). A forma genérica da equação (60) pode ser representada por:

${ }^{27}$ Segue o critério de arbitrariedade da p.44, anterior. 


$$
B_{t}^{P}=B_{t-1}^{P}-A_{t}^{P}-C_{t}^{P}
$$

A equação (61) é recursiva em $B_{t}^{P}$, na inexistência de prépagamento, para todo $t_{j} \neq \tau, j=0 \ldots N$. Neste caso, aplicando-se (4) em (60), tem-se:

$$
\begin{aligned}
& \sum_{j=1}^{N} C \cdot e^{-\int_{t}^{r_{j}} r(s) d s}=B_{t-1}^{P}-A_{t}^{P} \\
& \sum_{j=1}^{N} C \cdot e^{-\int_{1}^{T_{j} r(s) d s}}=B_{0}^{P}-\sum_{j=1}^{t} A_{j}^{P}
\end{aligned}
$$

Por $B_{0}^{P}=P$, pode-se reescrever a equação (63) em função do principal do contrato:

$$
\sum_{j=t}^{N} C \cdot e^{-\int^{T_{j}} r(s) d s}=P-\sum_{j=1}^{t} A_{j}^{P}
$$

$\mathrm{Na}$ existência de pré-pagamentos, pode-se estender a equação (64) na forma irrestrita:

$$
\sum_{j=1}^{N} C \cdot e^{-\int^{T_{j}} r(s) d s}=P-\sum_{j=1}^{t} A_{j}^{P}-C_{\tau}^{P} \cdot \mathrm{I}_{\{j=\tau\}}
$$


A equação (65) acima, em sua forma irrestrita ${ }^{28}$, define o valor do empréstimo, sob a ótica do mutuário, como o principal deduzido de todas suas respectivas amortizações. É outra forma de se determinar o valor atual de um contrato observado o prazo decorrido, em detrimento dos fluxos de caixa futuros, com o acumulo das amortizações passadas.

Os dados de evolução temporal dos meses subseqüentes são calculados aplicando-se as equações (58), (59) e (60), e devem preencher a base de dados no sentido vertical, tabela (1). Os resultados são obtidos de forma direta, pois dependem apenas dos resultados encontrados no período antecedente, $t-1$.

O gráfico (2), a seguir, apresenta a evolução do saldo do contrato usado nos exemplos anteriores:

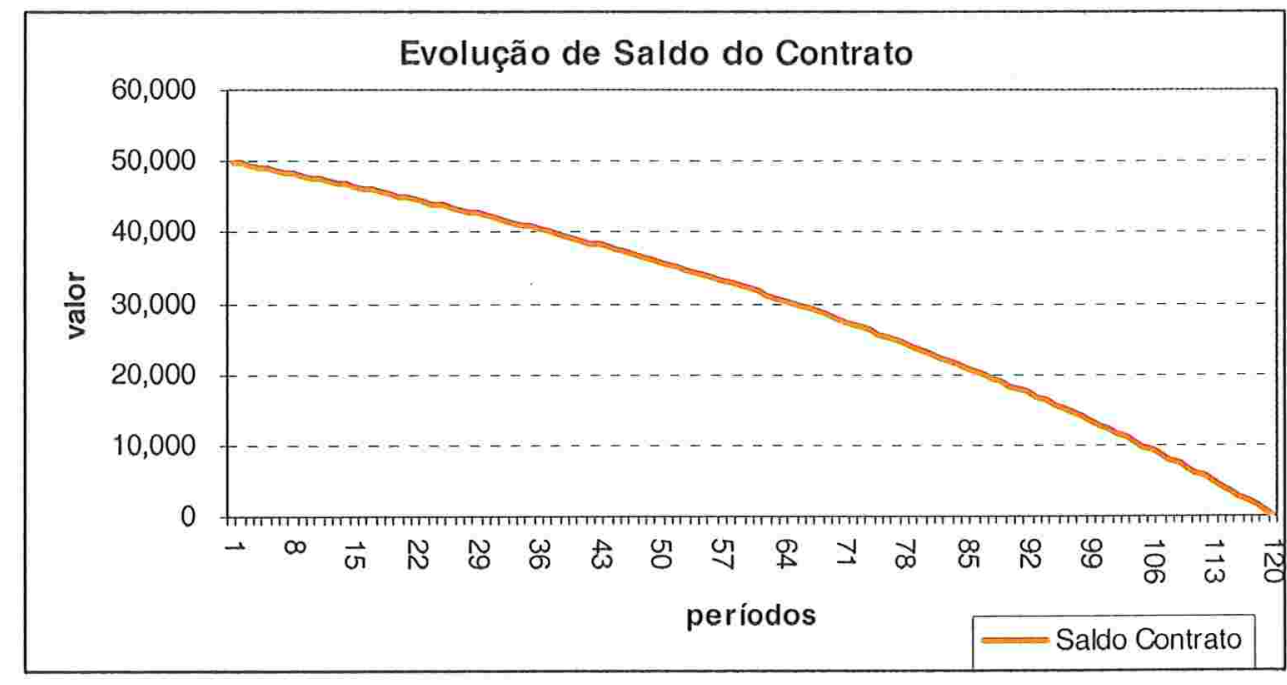

gráfico(2)

Denota-se a evolução no tempo do saldo do contrato, representada pelo gráfico(2), como $B_{j}^{P}$, para todo $j=0 \ldots 120$.

\footnotetext{
${ }^{28}$ Ressalta-se que permanece a premissa de ser possível a ocorrência de apenas um prépagamento ao longo da vida de um contrato.
} 
Ressalta-se que o contrato exemplificado não apresenta a ocorrência de um evento de pré-pagamento. As amortizações apresentadas são aquelas esperadas pelo pagamento das parcelas programadas constantes, $C$.

Os valores das respectivas amortizações do exemplo acima, podem ser observados no gráfico (3), abaixo:

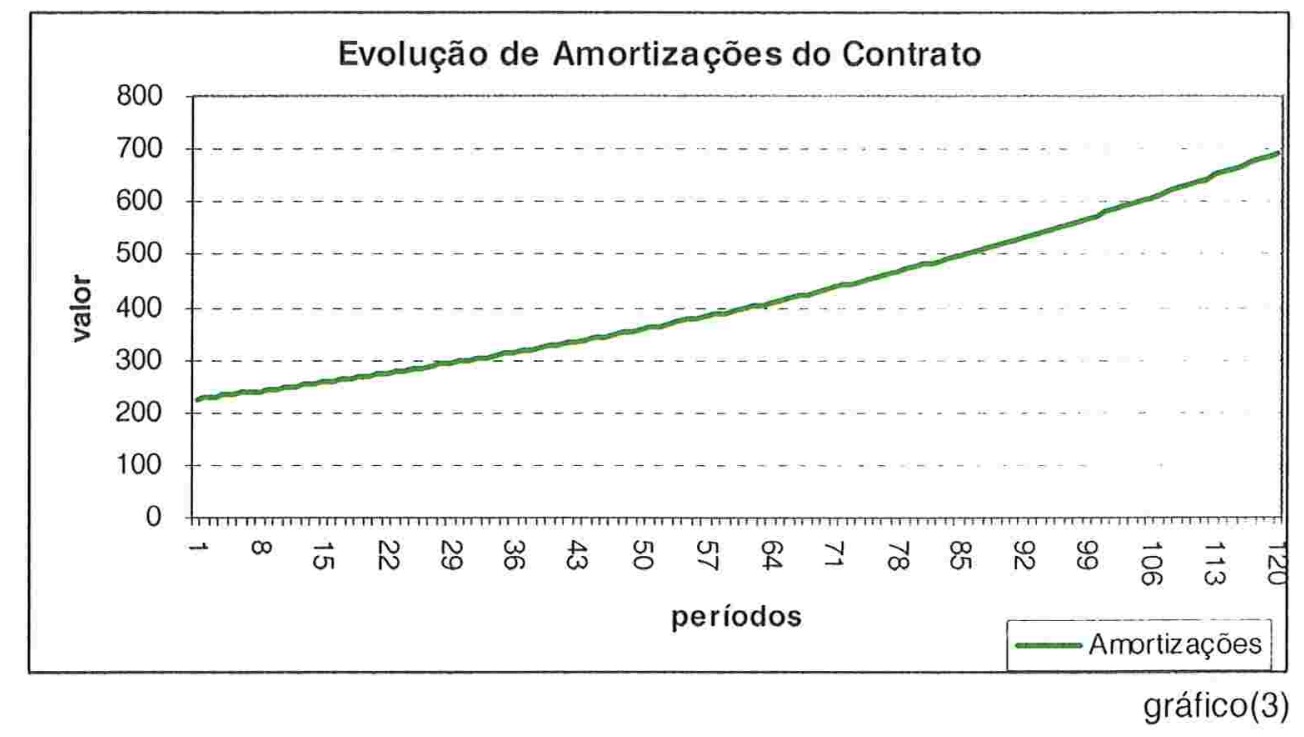

Denota-se a evolução das amortizações do contrato, representada pelo gráfico (3), por $A_{j}^{P}$, para todo $j=1 \ldots 120$, tal que $\sum_{j=0}^{120} A_{j}^{P}=B_{0}^{P 29}$.

${ }^{29}$ Referente equação (35), para $t=N$. 


\subsection{Análise dos Dados}

As representações gráficas anteriores são de um contrato simulado desconsiderando a opção de pré-pagamento durante a vida do contrato. De fato, caso houvesse restrições ao evento, os gráficos (2) e (3) representariam perfeitamente o perfil de um contrato de seu início ao seu vencimento. Contudo, a observação de dados históricos reais não materializa o perfil antes descrito para todos os contratos de uma carteira de crédito imobiliário.

Fluxos de pagamentos em montantes que diferem das parcelas programadas constantes são corriqueiramente observados. A detecção de eventos de pré-pagamento, quando da observação de dados reais de uma carteira, dá-se pela relação, já determinada, abaixo:

$$
C_{\tau}^{\text {observado }}-C_{\tau}^{\text {esperado }}=C_{\tau}^{P}
$$

onde,

$C_{\tau}^{\text {observado }}=$ pagamento efetivamente observado na ocorrência de pré-pagamento.

$C_{\tau}^{\text {esperado }}=$ pagamento esperado na ausência do evento de prépagamento, definido por $C$.

$C_{\tau}^{P}=$ valor referente ao pré-pagamento.

Deste modo, manipulando-se a base simulada para que todos os contratos apresentem individualmente ao menos um evento de pré-pagamento até seu respectivo vencimento, ao tomar-se o mesmo contrato usado nos exemplos anteriores, seu novo perfil de evolução temporal de saldo e 
amortizações diferem substancialmente das representações gráficas (2) e (3). Sua nova representação pode ser observada nos gráficos (4) e (5), a seguir:

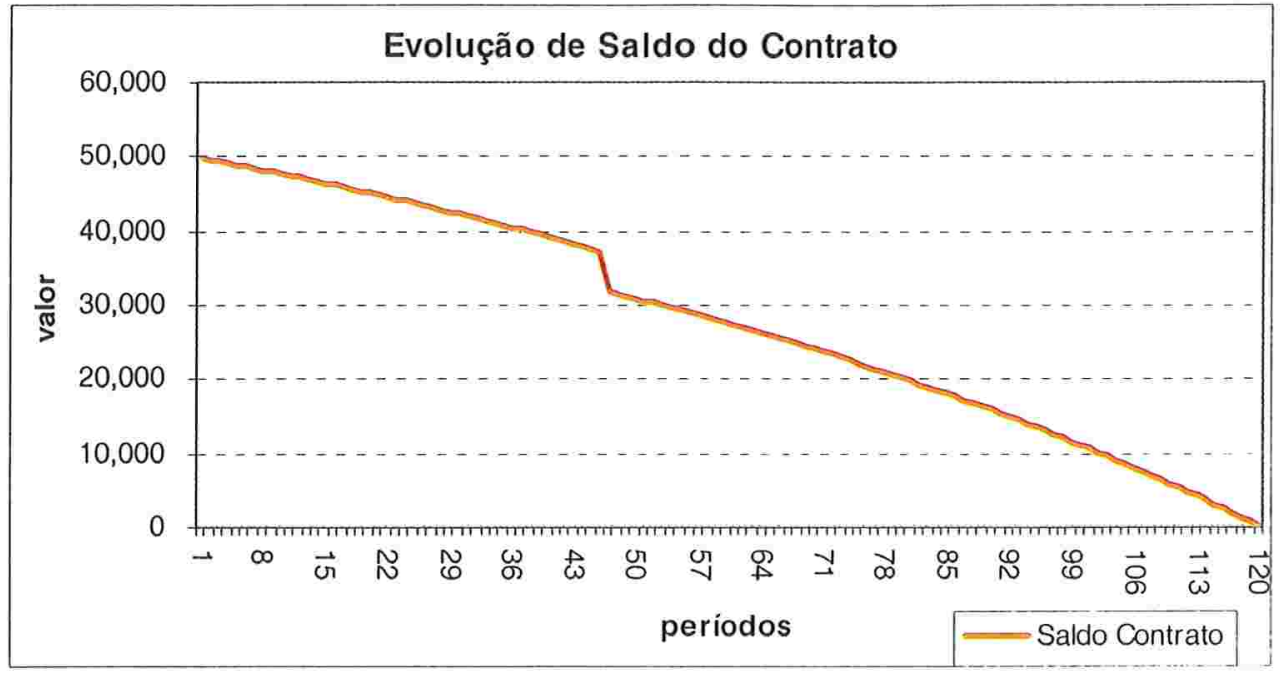

gráfico(4)

Denota-se a evolução no tempo do saldo do contrato, representada pelo gráfico(4), como $B_{j}^{P}$, para todo $j=0 \ldots 120$.

Nota-se a presença de uma brusca redução no saldo do contrato, no período 47 (quarenta e sete), que representa o momento do pré-pagamento.

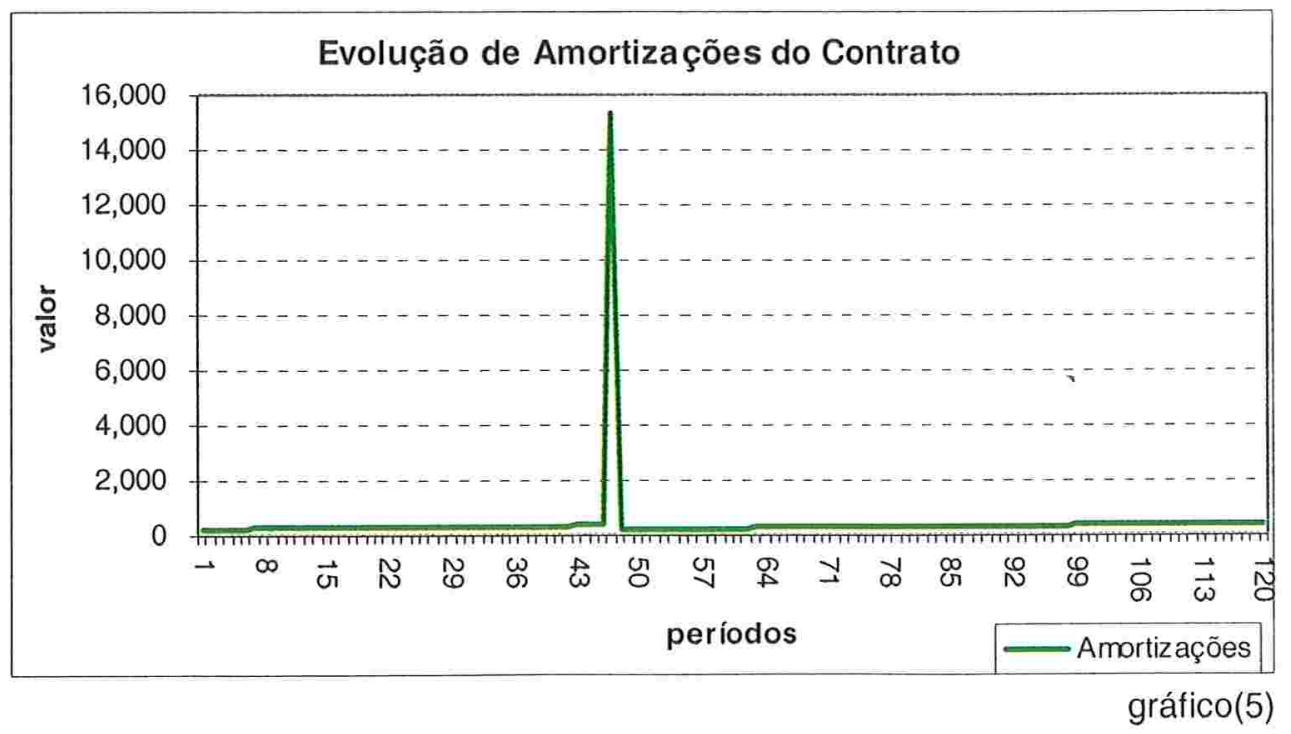


Denota-se a evolução das amortizações do contrato, representada pelo gráfico (5), por $A_{j}^{P}$, para todo $j=1 \ldots 120$ e $\tau=47$, tal que $\sum_{j=0}^{120} A_{j}^{P}+C_{\tau}^{P}=B_{0}^{P 30}$.

Como complemento à observação da redução inesperada do saldo do contrato, o gráfico (5) apresenta no período 47 (quarenta e sete) um valor de amortização do contrato superior ao programado, conforme o gráfico (3).

A nova estrutura de fluxos de pagamentos, antes constantes de acordo com gráfico (1), apresenta considerável alteração, como observado no gráfico (6) abaixo:

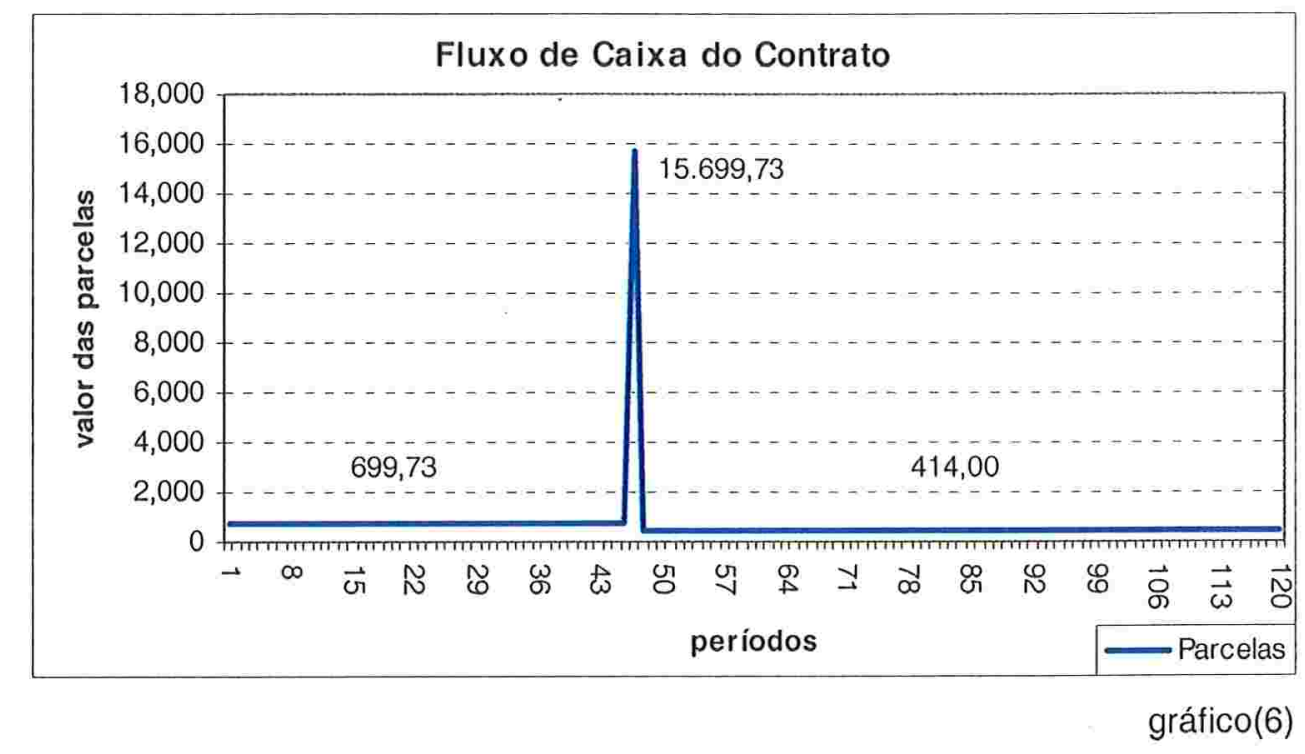

Ao observar-se o gráfico (6), pode-se extrair as variáveis:

$$
\begin{aligned}
& C_{j}=699,73 \text {, para } j<\tau, \\
& c_{j}=414,00, \text { para } j>\tau,
\end{aligned}
$$

\footnotetext{
${ }^{30}$ Referente equação (37), para $t=N$.
} 


$$
\begin{aligned}
& C_{\tau}^{P}=15.000,00, \\
& \tau=47 .
\end{aligned}
$$

O preenchimento da base de dados quanto a evolução no tempo do contrato em questão, respectivo a tabela (4), no período em que ocorre o prépagamento, apresenta os seguintes dados:

\begin{tabular}{|c|c|c|}
\hline $\begin{array}{c}\text { Período em } \\
\text { meses }\end{array}$ & \multicolumn{2}{|c|}{} \\
\hline \multirow{3}{*}{$47 \mathrm{M}$} & Amortização de Juros $\left(A_{47}^{r}\right)$ & 351,86 \\
\cline { 2 - 3 } & Amortização de Principal $\left(A_{47}^{P}\right)$ & $15.347,87$ \\
\cline { 2 - 3 } & Pré-pagamento $\left(C_{47}^{P}\right)$ & $15.000,00$ \\
\cline { 2 - 3 } & Saldo Atual do Contrato $\left(B_{47}^{P}\right)$ & $21.733,88$ \\
\hline
\end{tabular}

A simulação da base de dados está completa com o preenchimento da tabela referente à evolução temporal do contrato (verticalmente), para cada um dos contratos a ser simulado (horizontalmente). Completa a tabela em ambas dimensões, tem-se os dados consolidados da carteira de empréstimos imobiliários simulada.

A seguir, são apresentadas as análises executadas anteriormente para um único contrato simulado, para os dados da carteira consolidada, comparando os resultados na ausência de possíveis eventos de pré-pagamento com a ocorrência de pré-pagamentos, conforme as premissas especificadas: 

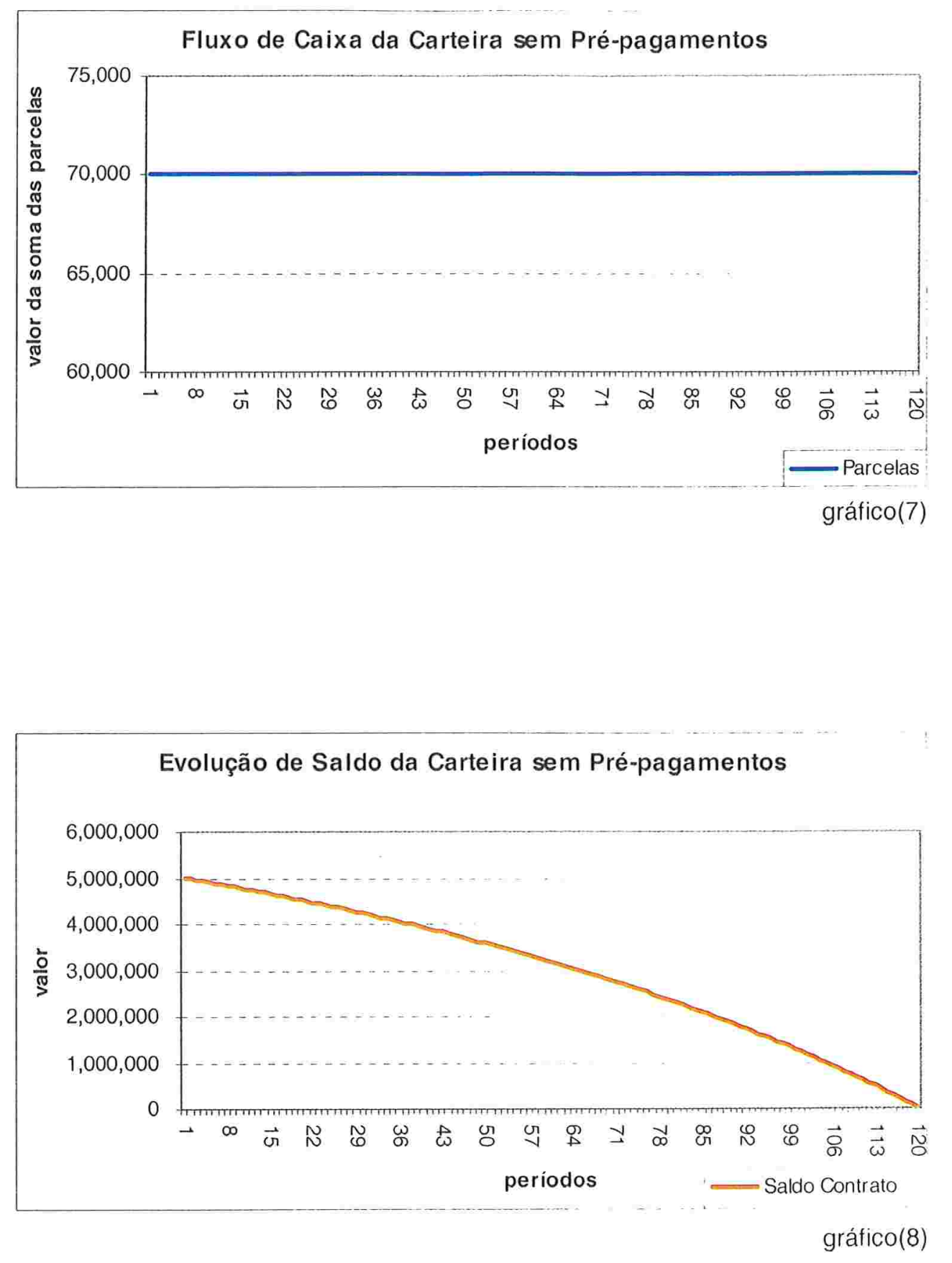


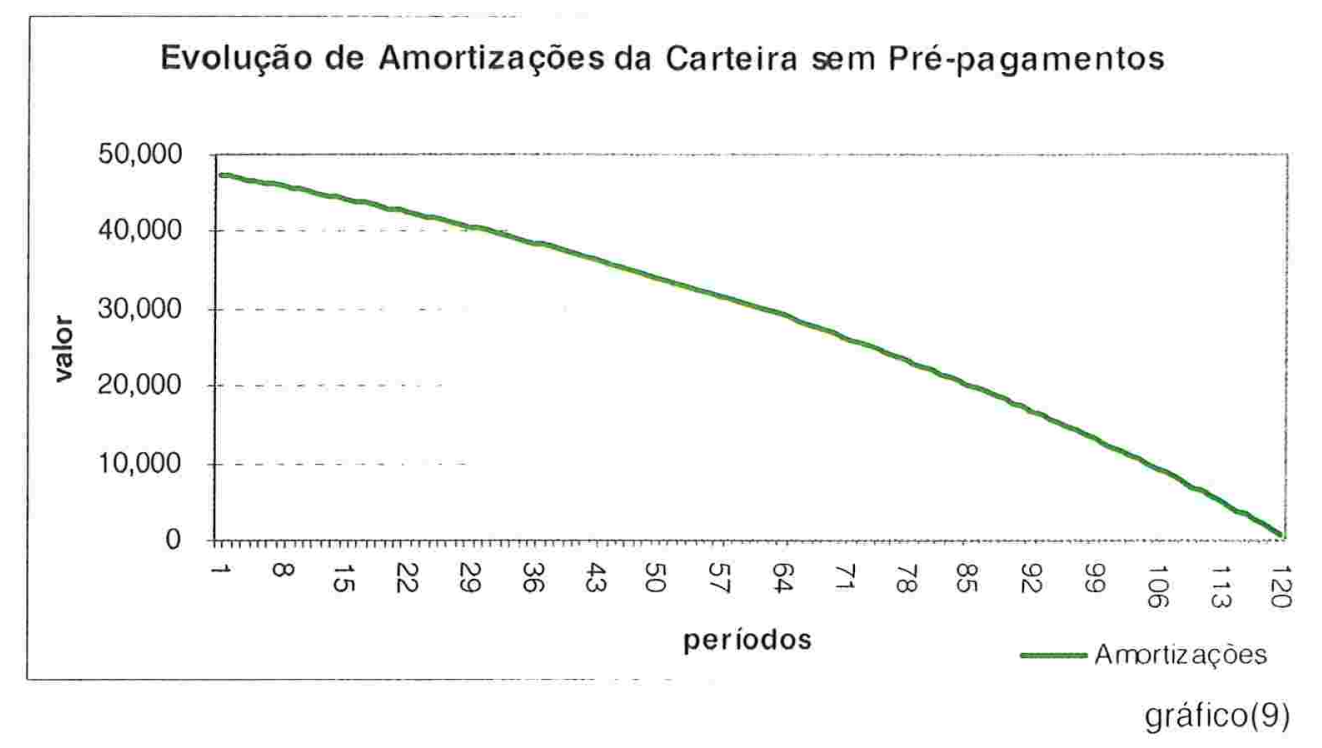

Os gráficos (7), (8) e (9) demonstram respectivamente o valor agregado das parcelas de todos os contrato em cada período, determinado por $\sum_{i=1}^{100} C_{i j}$, onde $i$ representa cada um dos contrato e os períodos, tal que $j=1 \ldots 120$, e as evoluções temporais do saldo da carteira e de suas respectivas amortizações periódicas. Ressalta-se que tais gráficos não apresentam a ocorrência de pré-pagamentos.

As análises da carteira, ao simular eventos de pré-pagamento, são apresentadas abaixo:

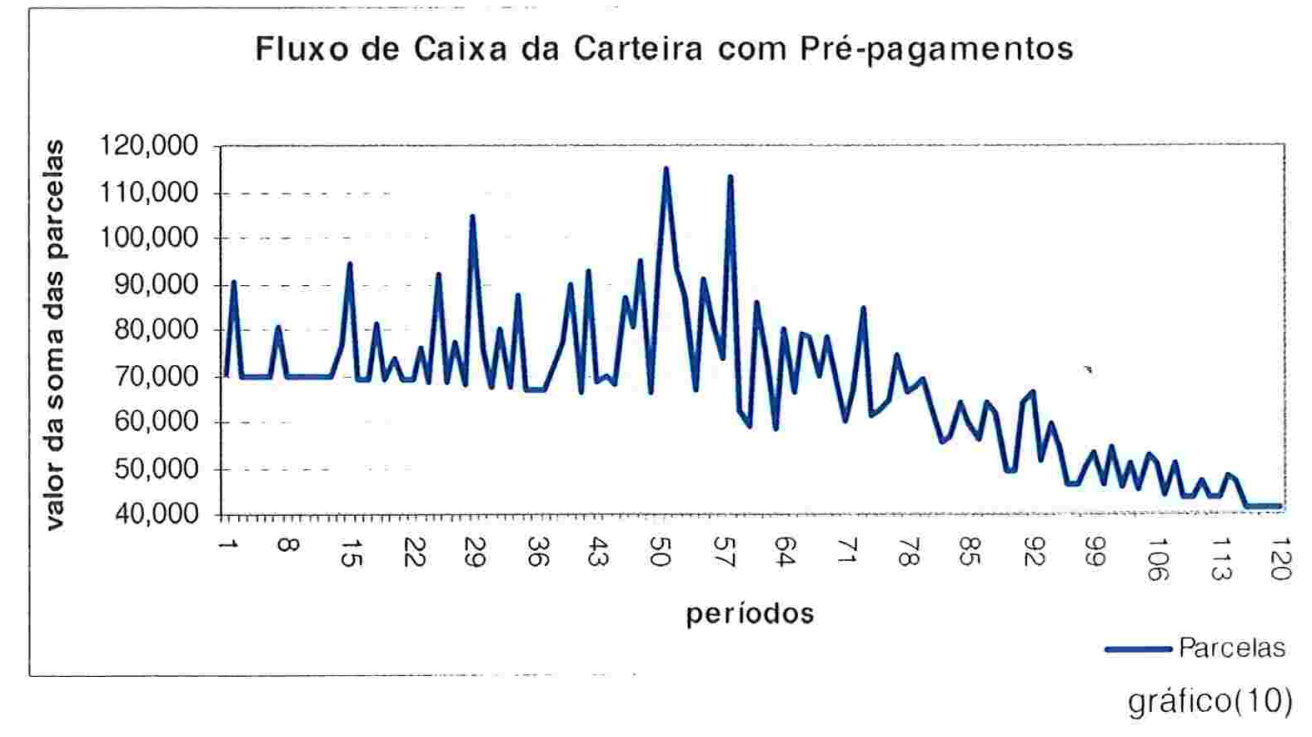


O gráfico (10) apresenta a estrutura de fluxos de pagamentos agregados da carteira, na presença de eventos de pré-pagamentos. É clara a alteração entre o perfil dos fluxos de pagamento na ausência e presença de prépagamentos, pela comparação dos gráficos (7) e (10). O gráfico (10) representa $\sum_{i=1}^{100} C_{i j}+C_{i \tau}^{P}$, onde $i$ representa cada um dos contratos e $j$ os períodos, tal que $j=1 \ldots 120$.

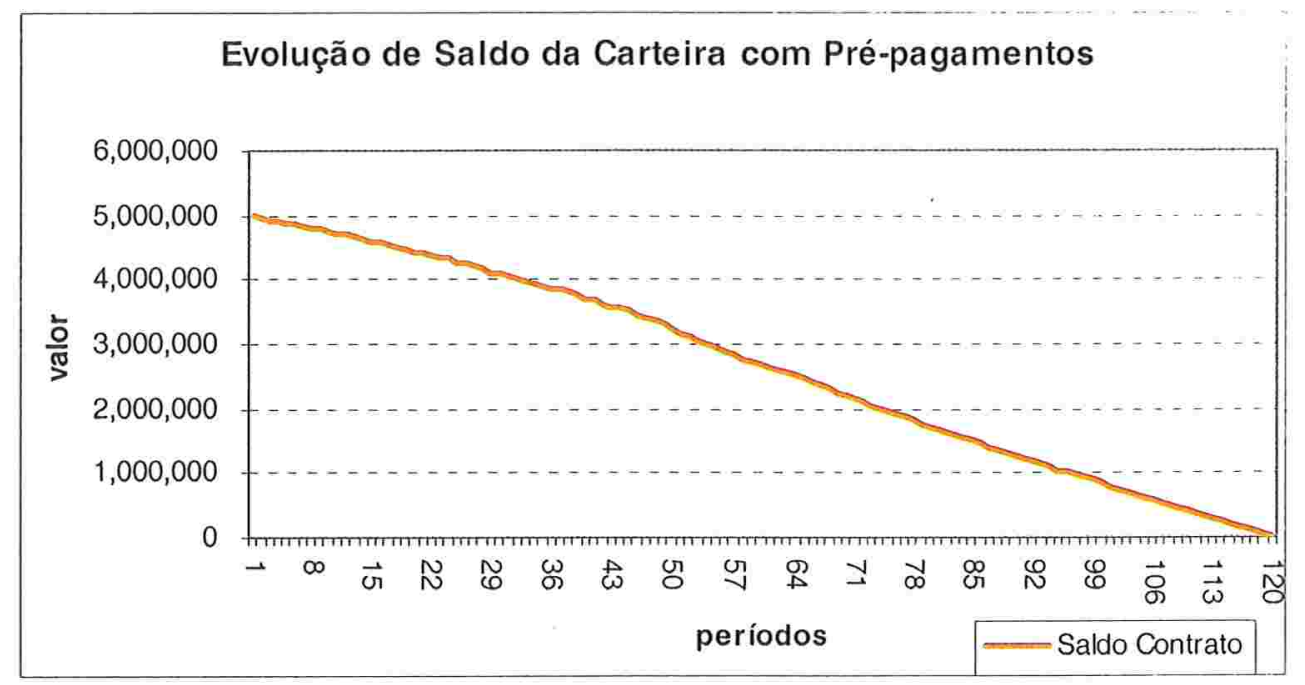

gráfico(11)

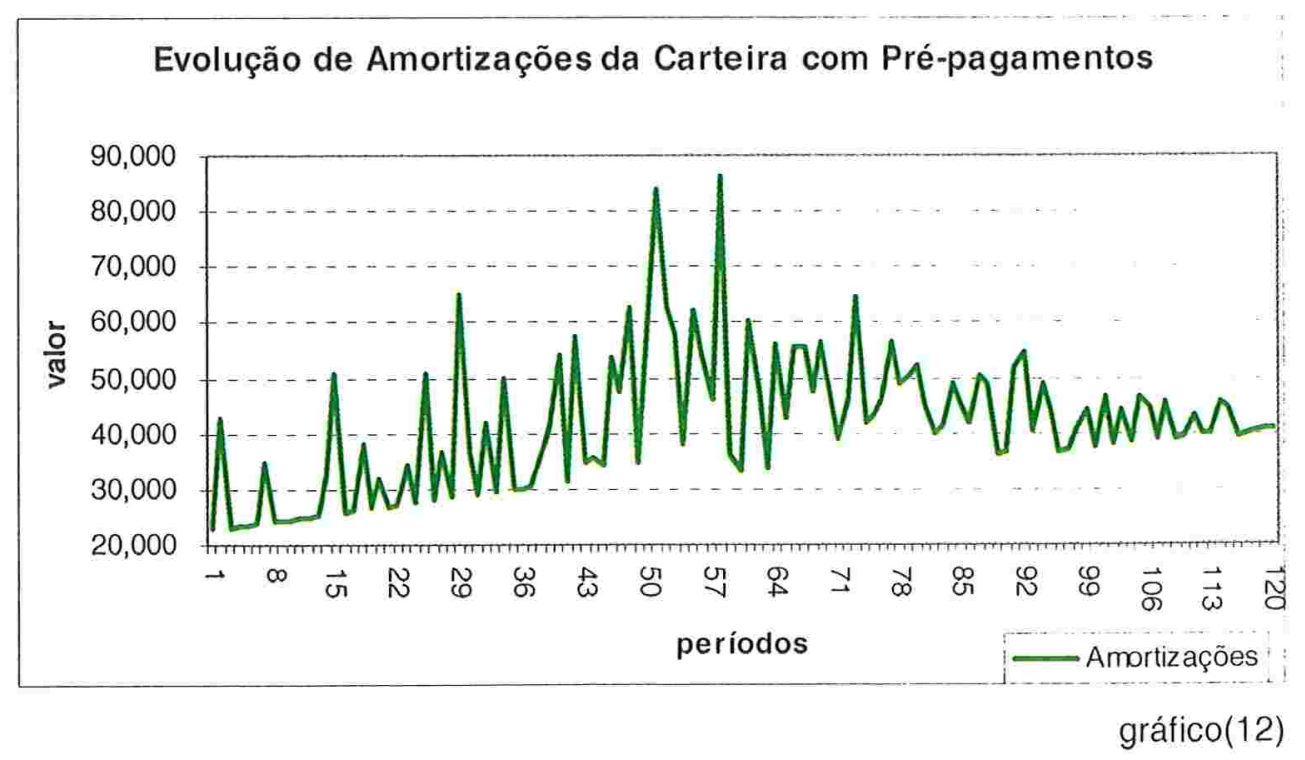


Os gráficos (11) e (12) demonstram a evolução temporal do saldo da carteira e de suas amortizações, respectivamente, contendo simulações de pré-pagamentos. Aos compará-los com os gráficos (8) e (9), nota-se que o saldo da carteira decai mais acentuadamente com as ocorrências de pré-pagamentos, ver gráfico (11). As amortizações da carteira assumem uma forma aleatória e caótica, ver gráfico (12), no lugar da forma crescente e suave, das amortizações esperadas.

Da análise da evolução temporal de cada um dos componentes da carteira extrai-se dois conjuntos de dados, provenientes do comportamento da massa de mutuários, fundamentais para a solução do modelo: a freqüência de pré-pagamentos e seus respectivos volumes. Respectivamente, esses conjuntos de dados serão responsáveis por definir os parâmetros $\lambda_{t}$ e $\delta_{l}$, do modelo.

Os resultados de freqüência obtidos podem ser observados na tabela (6) abaixo:

Freqüência de Pré-pagamentos Observados por Período

\begin{tabular}{|c|c|c|c|}
\hline Períodos (N) & Frequência observada & Períodos $(\mathbf{N})$ & Frequência observada \\
\hline \hline 1 & $0 \%$ & 61 & $3 \%$ \\
\hline 2 & $1 \%$ & 62 & $2 \%$ \\
\hline 3 & $0 \%$ & 63 & $0 \%$ \\
\hline 4 & $0 \%$ & 64 & $1 \%$ \\
\hline 5 & $0 \%$ & 65 & $2 \%$ \\
\hline 6 & $0 \%$ & 66 & $2 \%$ \\
\hline 7 & $1 \%$ & 67 & $3 \%$ \\
\hline 8 & $0 \%$ & 68 & $1 \%$ \\
\hline 9 & $0 \%$ & 69 & $1 \%$ \\
\hline 10 & $0 \%$ & 70 & $2 \%$ \\
\hline 11 & $0 \%$ & 71 & $1 \%$ \\
\hline 12 & $0 \%$ & 72 & $1 \%$ \\
\hline 13 & $0 \%$ & 73 & $2 \%$ \\
\hline 14 & $1 \%$ & 74 & $1 \%$ \\
\hline 15 & $1 \%$ & 75 & $1 \%$ \\
\hline 16 & $0 \%$ & 76 & $1 \%$ \\
\hline 17 & $0 \%$ & 77 & $1 \%$ \\
\hline 18 & $1 \%$ & 78 & $2 \%$ \\
\hline 19 & $0 \%$ & 79 & $1 \%$ \\
\hline 20 & $1 \%$ & 80 & $2 \%$ \\
\hline
\end{tabular}




\begin{tabular}{|c|c|c|c|}
\hline 21 & $0 \%$ & 81 & $1 \%$ \\
\hline 22 & $0 \%$ & 82 & $2 \%$ \\
\hline 23 & $1 \%$ & 83 & $1 \%$ \\
\hline 24 & $0 \%$ & 84 & $1 \%$ \\
\hline 25 & $1 \%$ & 85 & $1 \%$ \\
\hline 26 & $0 \%$ & 86 & $1 \%$ \\
\hline 27 & $2 \%$ & 87 & $1 \%$ \\
\hline 28 & $0 \%$ & 88 & $2 \%$ \\
\hline 29 & $1 \%$ & 89 & $0 \%$ \\
\hline 30 & $1 \%$ & 90 & $0 \%$ \\
\hline 31 & $0 \%$ & 91 & $1 \%$ \\
\hline 32 & $1 \%$ & 92 & $2 \%$ \\
\hline 33 & $0 \%$ & 93 & $1 \%$ \\
\hline 34 & $1 \%$ & 94 & $1 \%$ \\
\hline 35 & $0 \%$ & 95 & $1 \%$ \\
\hline 36 & $0 \%$ & 96 & $0 \%$ \\
\hline 37 & $0 \%$ & 97 & $0 \%$ \\
\hline 38 & $1 \%$ & 98 & $1 \%$ \\
\hline 39 & $1 \%$ & 99 & $1 \%$ \\
\hline 40 & $2 \%$ & 100 & $0 \%$ \\
\hline 41 & $0 \%$ & 101 & $1 \%$ \\
\hline 42 & $2 \%$ & 102 & $0 \%$ \\
\hline 43 & $1 \%$ & 103 & $1 \%$ \\
\hline 44 & $1 \%$ & 104 & $0 \%$ \\
\hline 45 & $1 \%$ & 105 & $1 \%$ \\
\hline 46 & $2 \%$ & 106 & $1 \%$ \\
\hline 47 & $1 \%$ & 107 & $0 \%$ \\
\hline 48 & $1 \%$ & 108 & $1 \%$ \\
\hline 49 & $1 \%$ & 109 & $0 \%$ \\
\hline 50 & $2 \%$ & 110 & $0 \%$ \\
\hline 51 & $1 \%$ & 111 & $1 \%$ \\
\hline 52 & $2 \%$ & 112 & $0 \%$ \\
\hline 53 & $1 \%$ & 113 & $0 \%$ \\
\hline 54 & $1 \%$ & 114 & $1 \%$ \\
\hline 55 & $3 \%$ & 115 & $1 \%$ \\
\hline 56 & $1 \%$ & 116 & $0 \%$ \\
\hline 57 & $2 \%$ & 117 & $0 \%$ \\
\hline 58 & $2 \%$ & 118 & $0 \%$ \\
\hline 59 & $1 \%$ & 119 & $0 \%$ \\
\hline 60 & $0 \%$ & 120 & $0 \%$ \\
\hline
\end{tabular}

Abaixo, tem-se a representação gráfica da tabela(6), acima, que demonstra com mais clareza a concentração de observações de prépagamentos ao longo dos períodos da carteira. 


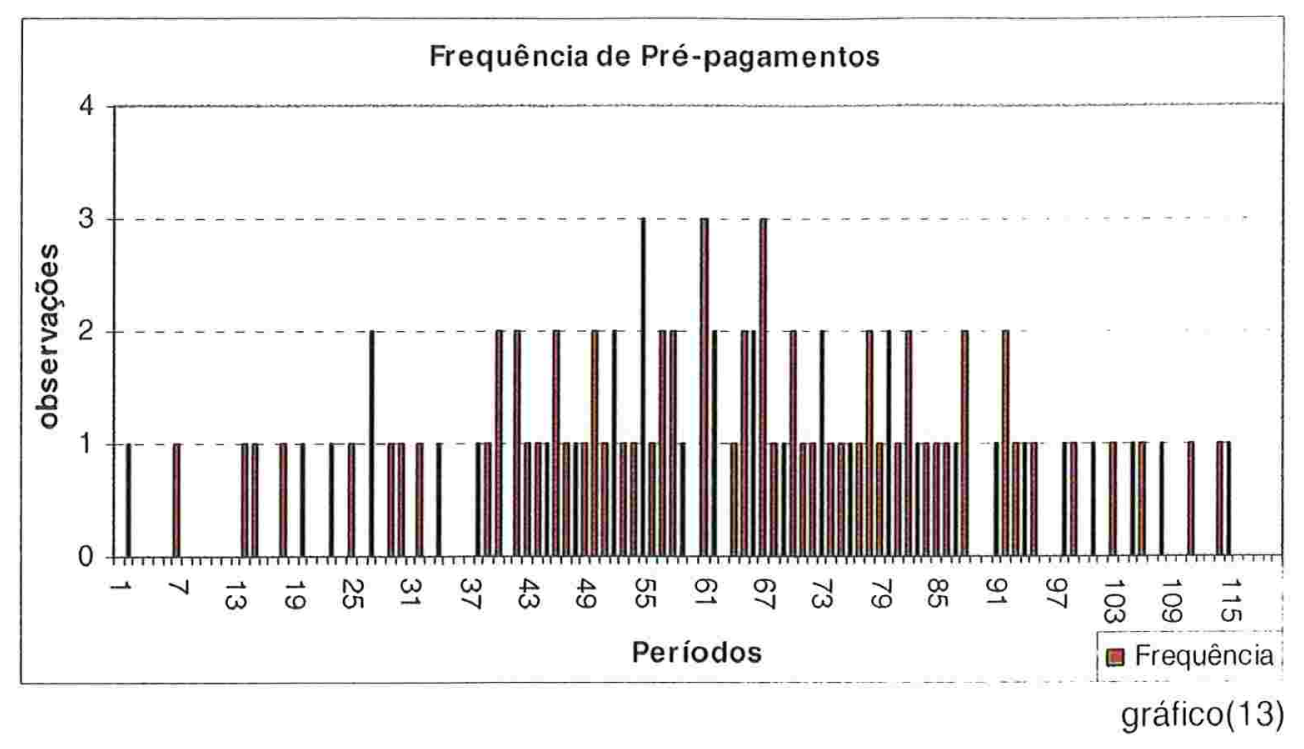

Os $\lambda_{j}$ extraídos podem ser observados na tabela (7) abaixo:

\begin{tabular}{|c|c|c|c|}
\hline Periodos & Lambda $t$ & Periodos & Lambda $t$ \\
\hline 1 & 0 & 61 & 0.05506 \\
\hline 2 & 0.01005 & 62 & 0.038466 \\
\hline 3 & 0 & 63 & 0 \\
\hline 4 & 0 & 64 & 0.019803 \\
\hline 5 & 0 & 65 & 0.040822 \\
\hline 6 & 0 & 66 & 0.04256 \\
\hline 7 & 0.010152 & 67 & 0.067441 \\
\hline 8 & 0 & 68 & 0.02353 \\
\hline 9 & 0 & 69 & 0.024098 \\
\hline 10 & 0 & 70 & 0.05001 \\
\hline 11 & 0 & 71 & 0.025975 \\
\hline 12 & 0 & 72 & 0.026668 \\
\hline 13 & 0 & 73 & 0.05557 \\
\hline 14 & 0.010257 & 74 & 0.028988 \\
\hline 15 & 0.010363 & 75 & 0.029853 \\
\hline 16 & 0 & 76 & 0.030772 \\
\hline 17 & 0 & 77 & 0.031749 \\
\hline 18 & 0.010471 & 78 & 0.066691 \\
\hline 19 & 0 & 79 & 0.035091 \\
\hline 20 & 0.010582 & 80 & 0.074108 \\
\hline 21 & 0 & 81 & 0.039221 \\
\hline 22 & 0 & 82 & 0.083382 \\
\hline 23 & 0.010695 & 83 & 0.044452 \\
\hline 24 & 0 & 84 & 0.04652 \\
\hline
\end{tabular}




\begin{tabular}{|c|c|c|c|}
\hline 25 & 0.010811 & 85 & 0.04879 \\
\hline 26 & 0 & 86 & 0.051293 \\
\hline 27 & 0.021979 & 87 & 0.054067 \\
\hline 28 & 0 & 88 & 0.117783 \\
\hline 29 & 0.011173 & 89 & 0 \\
\hline 30 & 0.0113 & 90 & 0 \\
\hline 31 & 0 & 91 & 0.064539 \\
\hline 32 & 0.011429 & 92 & 0.143101 \\
\hline 33 & 0 & 93 & 0.080043 \\
\hline 34 & 0.011561 & 94 & 0.087011 \\
\hline 35 & 0 & 95 & 0.09531 \\
\hline 36 & 0 & 96 & 0 \\
\hline 37 & 0 & 97 & 0 \\
\hline 38 & 0.011696 & 98 & 0.105361 \\
\hline 39 & 0.011834 & 99 & 0.117783 \\
\hline 40 & 0.024098 & 100 & 0 \\
\hline 41 & 0 & 101 & 0.133531 \\
\hline 42 & 0.024693 & 102 & 0 \\
\hline 43 & 0.012579 & 103 & 0.154151 \\
\hline 44 & 0.012739 & 104 & 0 \\
\hline 45 & 0.012903 & 105 & 0.182322 \\
\hline 46 & 0.026317 & 106 & 0.223144 \\
\hline 47 & 0.013423 & 107 & 0 \\
\hline 48 & 0.013606 & 108 & 0.287682 \\
\hline 49 & 0.013793 & 109 & 0 \\
\hline 50 & 0.028171 & 110 & 0 \\
\hline 51 & 0.014389 & 111 & 0.405465 \\
\hline 52 & 0.029414 & 112 & 0 \\
\hline 53 & 0.015038 & 113 & 0 \\
\hline 54 & 0.015267 & 114 & 0.693147 \\
\hline 55 & 0.047253 & 115 & 0 \\
\hline 56 & 0.016261 & 116 & 0 \\
\hline 57 & 0.033336 & 117 & 0 \\
\hline 58 & 0.034486 & 118 & 0 \\
\hline 59 & 0.0177 & 119 & 0 \\
\hline 60 & 0 & 120 & 0 \\
\hline
\end{tabular}

A estrutura a termo dos $\lambda_{t}$, ou seja, seus valores acumulados até cada um dos períodos, está representada no gráfico (14) abaixo: 


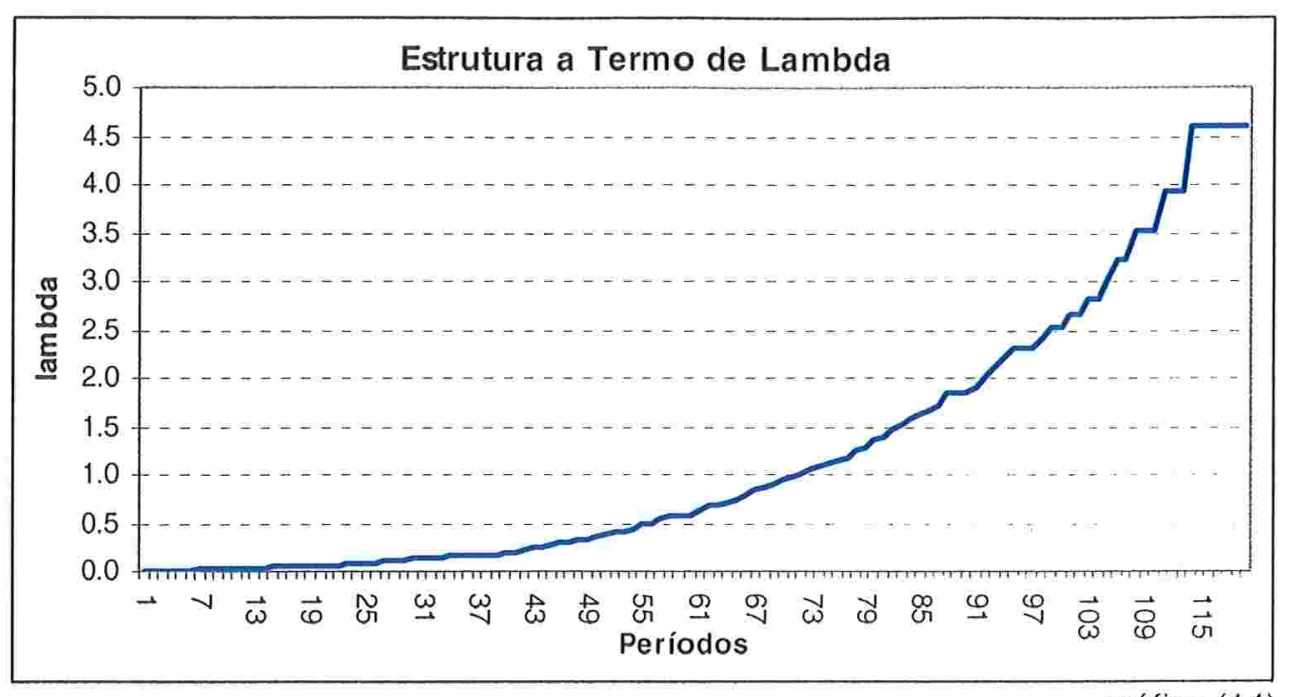

gráfico (14)

Por sua vez, os dados de volumes percentuais de pré-pagamentos podem ser observados na tabela (7) abaixo:

\begin{tabular}{|c|c|c|c|}
\hline Periodos & Delta $t$ & Periodos & Delta $t$ \\
\hline 1 & $0.000 \%$ & 61 & $30.509 \%$ \\
\hline 2 & $31.067 \%$ & 62 & $44.185 \%$ \\
\hline 3 & $0.000 \%$ & 63 & $0.000 \%$ \\
\hline 4 & $0.000 \%$ & 64 & $53.407 \%$ \\
\hline 5 & $0.000 \%$ & 65 & $20.065 \%$ \\
\hline 6 & $0.000 \%$ & 66 & $34.721 \%$ \\
\hline 7 & $15.645 \%$ & 67 & $29.370 \%$ \\
\hline 8 & $0.000 \%$ & 68 & $32.159 \%$ \\
\hline 9 & $0.000 \%$ & 69 & $57.413 \%$ \\
\hline 10 & $0.000 \%$ & 70 & $20.264 \%$ \\
\hline 11 & $0.000 \%$ & 71 & $17.281 \%$ \\
\hline 12 & $0.000 \%$ & 72 & $37.034 \%$ \\
\hline 13 & $0.000 \%$ & 73 & $65.826 \%$ \\
\hline 14 & $30.031 \%$ & 74 & $40.795 \%$ \\
\hline 15 & $71.193 \%$ & 75 & $20.431 \%$ \\
\hline 16 & $0.000 \%$ & 76 & $42.626 \%$ \\
\hline 17 & $0.000 \%$ & 77 & $62.158 \%$ \\
\hline 18 & $17.581 \%$ & 78 & $22.740 \%$ \\
\hline 19 & $0.000 \%$ & 79 & $42.624 \%$ \\
\hline 20 & $10.422 \%$ & 80 & $30.470 \%$ \\
\hline 21 & $0.000 \%$ & 81 & $59.385 \%$ \\
\hline 22 & $0.000 \%$ & 82 & $10.876 \%$ \\
\hline 23 & $13.626 \%$ & 83 & $21.833 \%$ \\
\hline
\end{tabular}




\begin{tabular}{|c|c|c|c|}
\hline 24 & $0.000 \%$ & 84 & $46.435 \%$ \\
\hline 25 & $36.354 \%$ & 85 & $30.068 \%$ \\
\hline 26 & $0.000 \%$ & 86 & $71.544 \%$ \\
\hline 27 & $18.140 \%$ & 87 & $68.611 \%$ \\
\hline 28 & $0.000 \%$ & 88 & $36.031 \%$ \\
\hline 29 & $99.284 \%$ & 89 & $0.000 \%$ \\
\hline 30 & $11.761 \%$ & 90 & $0.000 \%$ \\
\hline 31 & $0.000 \%$ & 91 & $65.909 \%$ \\
\hline 32 & $21.614 \%$ & 92 & $49.796 \%$ \\
\hline 33 & $0.000 \%$ & 93 & $43.003 \%$ \\
\hline 34 & $35.594 \%$ & 94 & $60.643 \%$ \\
\hline 35 & $0.000 \%$ & 95 & $96.579 \%$ \\
\hline 36 & $0.000 \%$ & 96 & $0.000 \%$ \\
\hline 37 & $0.000 \%$ & 97 & $0.000 \%$ \\
\hline 38 & $24.323 \%$ & 98 & $21.838 \%$ \\
\hline 39 & $23.529 \%$ & 99 & $43.593 \%$ \\
\hline 40 & $24.290 \%$ & 100 & $0.000 \%$ \\
\hline 41 & $0.000 \%$ & 101 & $82.369 \%$ \\
\hline 42 & $38.368 \%$ & 102 & $0.000 \%$ \\
\hline 43 & $18.711 \%$ & 103 & $88.584 \%$ \\
\hline 44 & $9.265 \%$ & 104 & $0.000 \%$ \\
\hline 45 & $5.614 \%$ & 105 & $47.062 \%$ \\
\hline 46 & $36.983 \%$ & 106 & $79.177 \%$ \\
\hline 47 & $40.451 \%$ & 107 & $0.000 \%$ \\
\hline 48 & $62.700 \%$ & 108 & $49.110 \%$ \\
\hline 49 & $9.972 \%$ & 109 & $0.000 \%$ \\
\hline 50 & $46.210 \%$ & 110 & $0.000 \%$ \\
\hline 51 & $98.958 \%$ & 111 & $52.499 \%$ \\
\hline 52 & $48.602 \%$ & 112 & $0.000 \%$ \\
\hline 53 & $65.599 \%$ & 113 & $0.000 \%$ \\
\hline 54 & $15.682 \%$ & 114 & $81.029 \%$ \\
\hline 55 & $44.867 \%$ & 115 & $83.703 \%$ \\
\hline 56 & $57.220 \%$ & 116 & $0.000 \%$ \\
\hline 57 & $24.586 \%$ & 117 & $0.000 \%$ \\
\hline 58 & $60.486 \%$ & 118 & $0.000 \%$ \\
\hline 59 & $7.226 \%$ & 119 & $0.000 \%$ \\
\hline 60 & $0.000 \%$ & 120 & $0.000 \%$ \\
\hline
\end{tabular}

É necessária, também, a informação da curva de juros extraída do mercado à vista, como fator de desconto de mercado $i(s)$. Para tal, foi simulada uma curva de taxas de juros de mercado, descrita pelo gráfico (15) abaixo: 


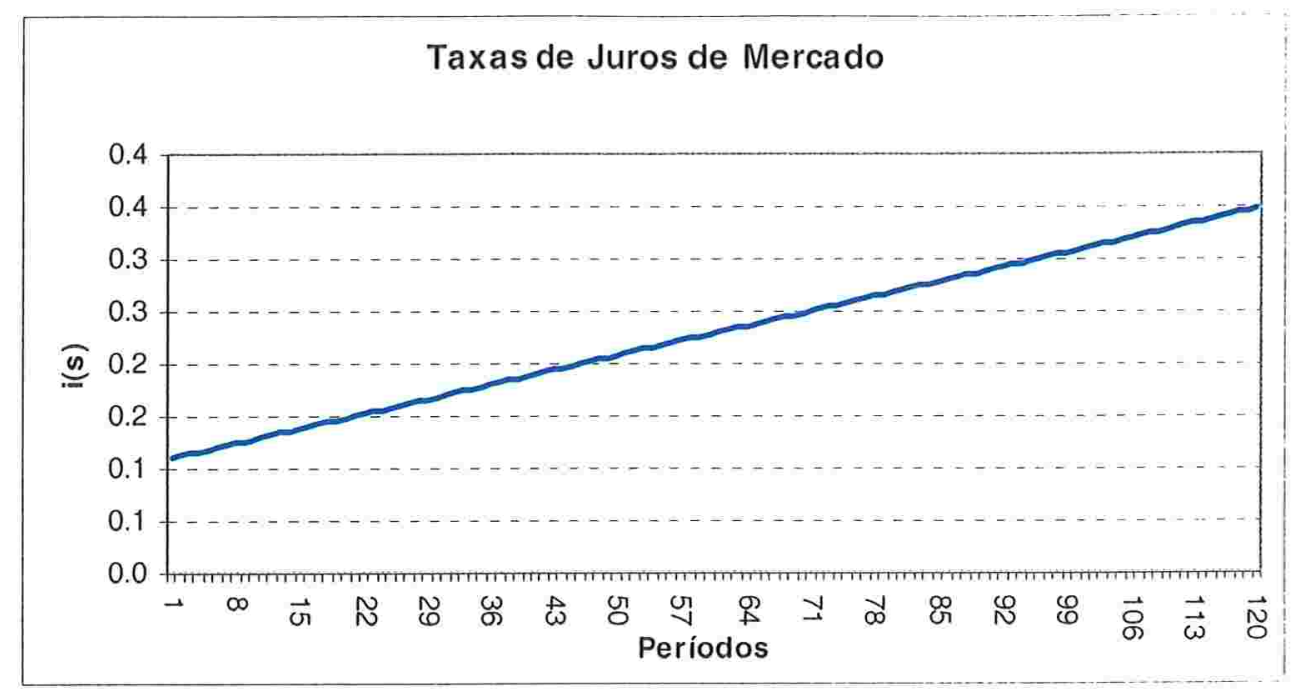

gráfico(15)

\subsection{Resultados Calculados}

O modelo foi testado para um contrato de principal $P=50.000$, taxa contratual $r=12 \%$ e prazo $T=10$ anos. Esse contrato possui as características da média dos contratos no sistema financeiro, quando da execução desta pesquisa.

Os resultados obtidos da aplicação dos parâmetros extraídos da base de dados, são demonstrados a seguir:

$$
\begin{aligned}
& \Gamma=0,952227 \\
& c=684,74 \\
& C_{\tau}^{P}=859,92 \\
& \bar{\tau}=59,87
\end{aligned}
$$




\section{CONCLUSÃO}

De acordo com os resultados obtidos, podemos concluir que de fato a estrutura de pagamentos de um contrato imobiliário é modificada pela presença do risco de pré-pagamento.

Em um contrato exemplo de principal $P=50.000$, taxa contratual $r=12 \%$ e prazo $T=10$ anos, típico contrato médio observado no sistema financeiro brasileiro, seria esperado um fluxo de pagamentos constantes em parcelas $C=719,10$, pagos períodos mensais $j=0,1, \ldots, 120$.

$\mathrm{Na}$ presença de pré-pagamento, o contrato assume um fluxo esperado de pagamentos, conforme:
a) Parcelas anteriores ao pré-pagamento:
$C=719,10$
b) Fluxo de antecipação de pagamento:
$C_{\tau}^{P}=859,92$

tempo esperado de ocorrência de $C_{\tau}^{P}$ :

$\bar{\tau}=59,87$ meses

c) Parcelas posteriores ao pré-pagamento:

$c=684,74$

Este novo perfil de fluxos de pagamento está demonstrado no gráfico (16) abaixo: 


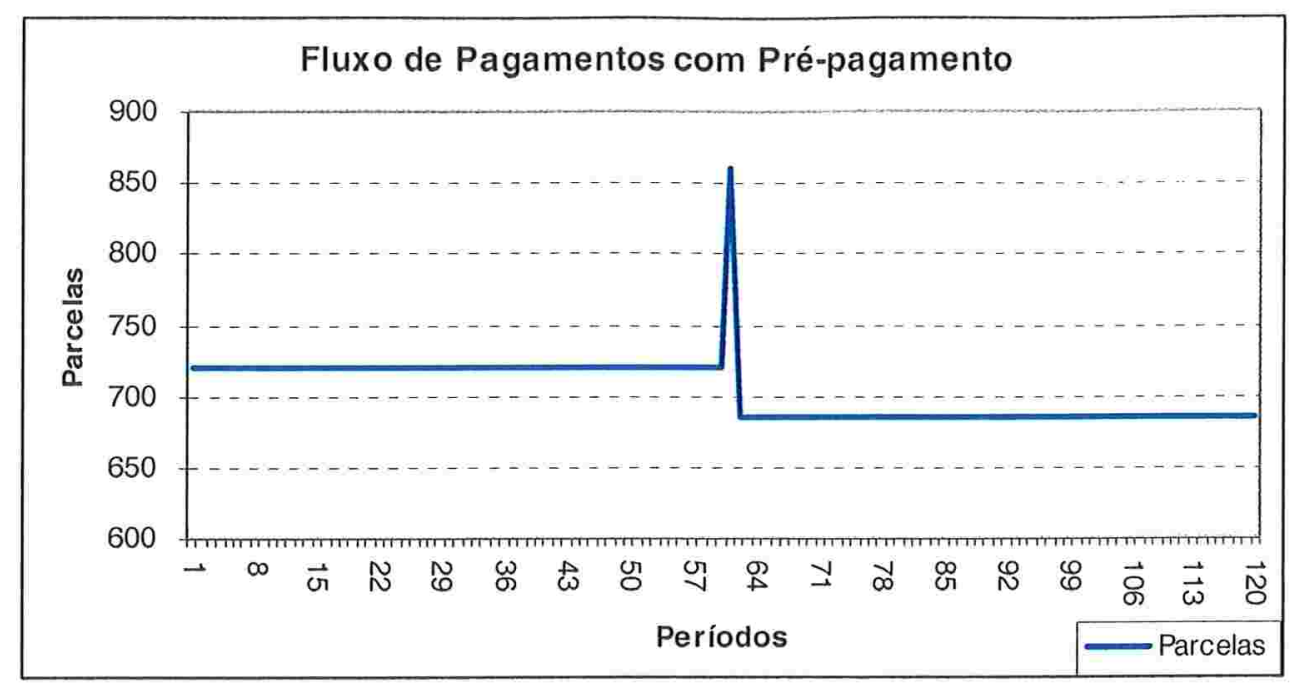

gráfico(16)

Neste exemplo, o evento de pré-pagamento não exerce um efeito de grandes proporções sobre o valor de mercado do contrato $V_{o}^{P}$. Contudo, esse efeito depende do diferencial entre a taxa de juros do contrato e as taxas de juros vigentes no mercado, dos percentuais de pré-pagamento $\delta$, extraídos e do processo de intensidade $\lambda_{t}$, também extraídos da base de dados.

O valor de mercado sem pré-pagamento $V_{0}^{A}$ e o valor de mercado com pré-pagamento denotado no momento $V_{0}^{A^{*}}$, estão demonstrados abaixo:

$$
\begin{aligned}
& V_{0}^{A}=33.919,80 \\
& V_{0}^{A^{*}}=33.699,77
\end{aligned}
$$




\section{Simulações}

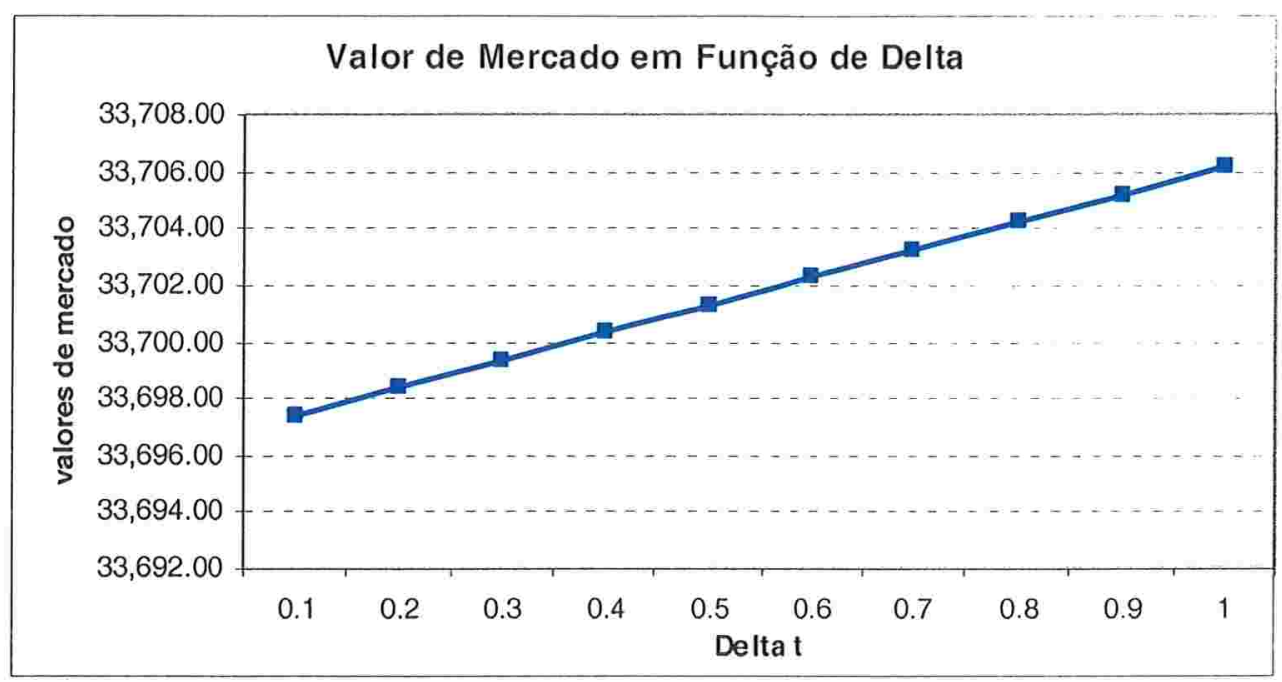

gráfico(17)

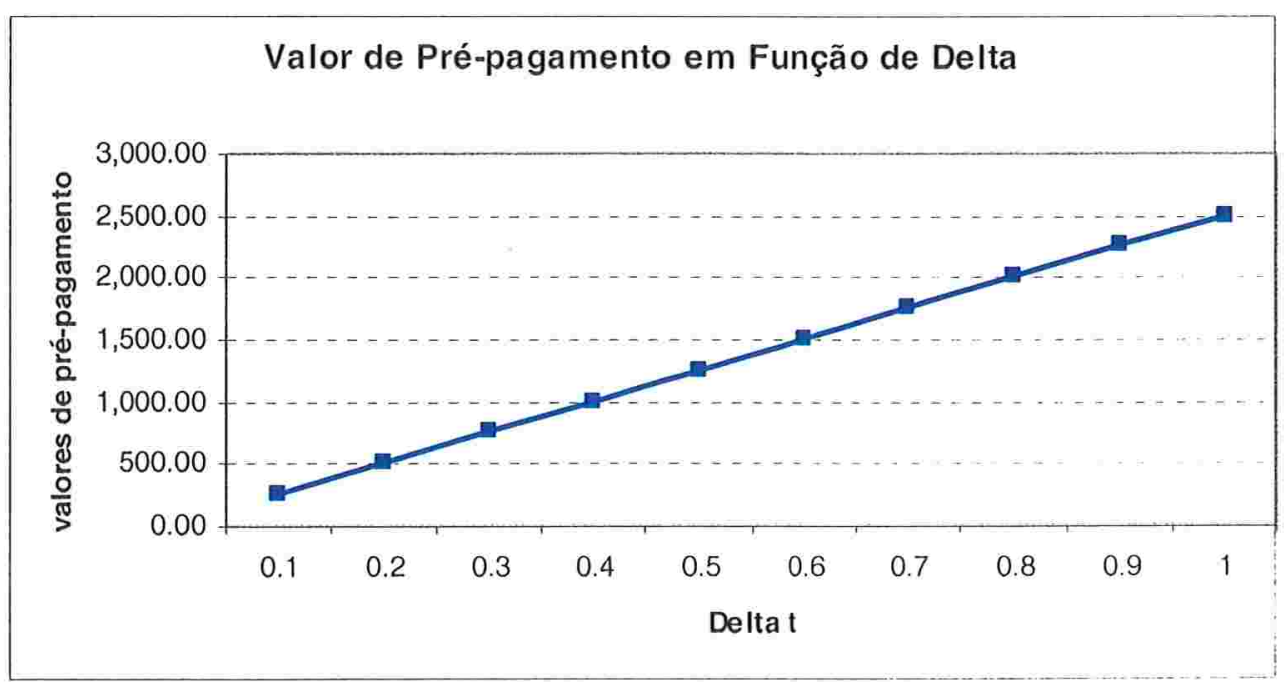

gráfico(18) 


\section{Estratégia de Hedge}

Instituições Financeiras seguem diferentes estratégias de hedge, cada uma de acordo com o seu perfil.

Uma das estratégias possiveis é o hedge pela duration. Duration é o prazo médio ponderado pelo valor presente, descontado pelos fatores de mercado, de cada um dos fluxos de pagamento $C$.

Se $D^{A}$ denota a duration de um contrato de empréstimo imobiliário, então:

$$
D^{A}=\frac{\sum_{j=0}^{N} C \cdot F_{0}^{M}\left(0, T_{j}\right) \cdot j}{\sum_{j=0}^{N} C \cdot F_{0}^{M}\left(0, T_{j}\right)}
$$

O resultado de $D^{A}$ é um valor expresso na mesma base de $j$, neste trabalho em meses. Na prática, uma operação de um único fluxo de caixa de prazo $D^{A}$ e valor de mercado $V_{0}^{A}$ tem a mesma sensibilidade à movimentos paralelos na curva de mercado em seu valor de mercado, quanto outra de estrutura mais complexa de fluxo de caixa, porém com a mesma duration $D^{A}$.

Isto implica que, para uma estratégia de hedge mais eficiente, uma determinada instituição financeira deveria utilizar a duration de um contrato calculada a partir do fluxo de pagamentos ajustado ao risco de pré-pagamento.

Usando o mesmo exemplo anterior, o resultado da duration sem considerar pré-pagamento $D^{A}$ e o resultado da duration considerando prépagamento $D_{P}^{A}$, são:

$$
\begin{aligned}
& D_{A}=34,40 \\
& D_{A}^{P}=34,07
\end{aligned}
$$


Esse resultado mostra que a operação de hedge mais eficiente a este contrato que considera a existência de pré-pagamento deve ter prazo menor, aproximadamente em seis meses, que do mesmo contrato, porém desconsiderando a existência de pré-pagamento. 


\section{Bibliografia}

Archer, W. R. e Ling, D. C., 1993, "Pricing Mortgage-Backed Securities: Integrating Optimal Call and Empirical Models of Prepayment", Journal of the American Real Estate and Urban Economics Association, vol. 21, p. 373-404.

Benninga, S., and Wiener, Z. "Binomial Term Structure Models". Matematica in Educational Research, vol. 7., no. 3 (1998).

Dunn, K. B., and C. S. Spatt, 1986, "The Effect of Refinancing Costs and Market Imperfections on the Optimal Call Strategy and the Pricing of Debt Contracts.", Working paper, Canegie-Mellon University.

Dunn, K. B., e McConnel, J. J., 1981, "A Comparison of Alternative Models for Pricing GNMA Mortgage-Backed Securities", The Journal of Finance, vol. 36, p. $471-487$.

Dunn, K. B., e McConnel, J. J., 1981, "Valuation of GNMA Mortgage-Backed Securities", The Journal of Finance, vol. 36, p. 599-616.

Hansen, L.P., and K. J. Singleton, 1982, (Generalized Instrumental Variables Estimators", Econometrica, 50,1029-1054.

Hayre, L. e Young, R., "Anatomy of Prepayments - The Salomon Smith Barney Prepayment Model",

McConnel, J. J., e Singh, M., 1994, "Rational Prepayment and the Valuation of Collateralized Mortgage Obligations", The Journal of Finance, vol. XLIX, p. 891-921. 
Perry, S., Robinson, S. e Rowland J., 2001, "A Study of Mortgage Prepayment Risk", Institute of Actuaries and Faculty of Actuaries.

Quigley, J. M. e Order, R. V., 1990, "Efficiency in the Mortgage Market: The Borrower's Perspective", Journal of the American Real Estate and Urban Economics Association, vol. 18, p. 237-252

Saunders, A., "Financial Institutions Management", $2^{\text {nd }}$. edição, 1994.

Schwartz, E. S., and W. N. Torous, 1989, "Prepayment on Fixed Rate Mortgage-Backed Securities", Journal of Finance, 44, 375-392.

Stanton, R. H. "Rational Prepayment and the Valuation of MortgageBacked Securities" Working Paper, U.C. Berkeley (1995). Forthcoming Review of Financial Studies.

Stanton, R. H. e Wallace, N. "Mortgage Choice: What's the Point?", Working Paper, U.C. Berkeley (1997), Forthcoming Real Estate Economics. 


\section{APÊNDICE}

Sub calculo_GAMA()

'Calcula o fator de ajuste de risco de pré-pagamento

'Dimensiona variáveis

$\operatorname{Dim} r(1$ To 300) As Double 'fator do contrato

Dim i(1 To 300) As Double 'fator de mercado

Dim I(1 To 300) As Double 'lambda

Dim d(1 To 300) As Double 'delta

$\operatorname{Dim} N$ (1 To 300) As Integer 'período corrente

Dim Bt(1 To 300) As Double 'solucão da somatoria de fluxos de caixa (auxiliar)

Dim tal(1 To 300) As Double 'solução de tal medio

Dim tal_acum As Double '(auxiliar)

Dim Tf As Integer 'período final

Dim t As Integer 'período inicial

Dim j As Integer 'contador 1

Dim k As Integer 'contador 2

Dim y As Integer 'contador 3

Dim z As Integer 'contador 4

$\mathrm{Tf}=$ Plan1 $\cdot$ Range $(" \mathrm{~N} ")$

$\mathrm{p}=$ Plan1.Range("P")

$\mathrm{t}=$ Plan1.Range("t")

For $\mathrm{j}=1$ To $\mathrm{Tf}$ 'preenche os vetores

$N(j)=$ Plan1.Cells $(j+9,1)$

$r(j)=$ Plan 1.Cells $(j+9,5)$

$i(j)=$ Plan1.Cells $(j+9,6)$

$I(j)=$ Plan1.Cells $(j+9,3)$

$d(j)=$ Plan1.Cells $(j+9,4)$

Next j

'Calcula E[B(t)]---

For $\mathrm{j}=1$ To $\mathrm{Tf}$

For $y=1$ To $j$

I_acum_1 = I_acum_1 + I(y)

For $\mathrm{k}=1$ To $\mathrm{y}$

I_acum_2 = I_acum_2 + I(k)

Next k

int_1 $=$ int_1 $+\mathrm{d}(\mathrm{y}){ }^{*} \mathrm{r}(\mathrm{y}) / \mathrm{i}(\mathrm{y}){ }^{*} \mathrm{I}(\mathrm{y}){ }^{*} \operatorname{Exp}\left(-\mathrm{I} \_\right.$acum_2 $)$

I_acum_2 =0 


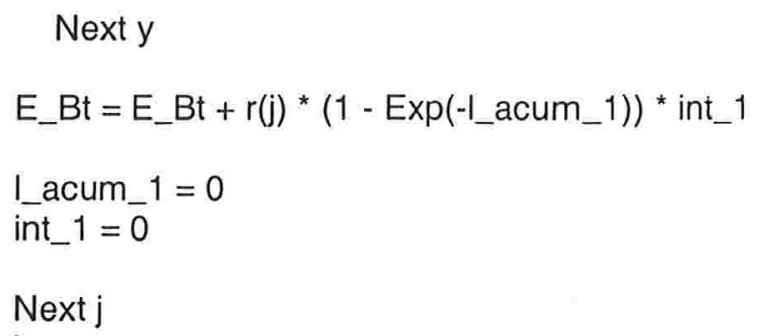


$\operatorname{tal}(j)=N(j){ }^{*} I(j){ }^{*} \operatorname{Exp}\left(-I \_a c u m \_1\right)$

tal_acum $=\operatorname{tal}(j)+$ tal_acum

I_acum_1 = 0

Next j

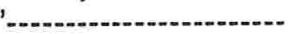

'Escreve resultados na planilha---.--..-..-.-

Plan1.Cells $(3,9)=E \_B t$

Plan1.Cells $(4,9)=a$

Plan1.Cells $(5,9)=b$

Plan1.Cells $(6,9)=$ tal_acum

End Sub 